\title{
Cell and toxicant specific phosphorylation of conexin43: effects of lindane and TPA on rat myometrial and WB-F344 liver cell gap junctions
}

\author{
R. Loch-Caruso, M.M. Galvez, K. Brant and D. Chung \\ Department of Environmental Health Sciences, University of Michigan, Ann Arbor, MI, USA
}

Received 23 June 2003; accepted 26 March 2004

Keywords: connexin43, gap junction, $\gamma$-hexachlorocyclohexane, lindane, myometrial cells, TPA

\begin{abstract}
Previous studies showed that the pesticide lindane ( $\gamma$-hexachlorocyclohexane) inhibits gap junction intercellular communication in rat myometrial cells. The present study tested the hypothesis that lindane and the phorbol ester 12-O-tetradecanoylphorbol-13-acetate (TPA) inhibit gap junction communication in rat myometrial and liver $\mathrm{WB}^{\mathrm{r}}$-F344 cells by the common mechanism of increasing phosphorylation of the gap junction protein connexin43. We evaluated changes of connexin 43 phosphorylation using Western blot of standard SDS-PAGE gels and cell immunostaining, and we monitored gap junction communication using microinjection and transfer of Lucifer yellow dye. Exposure of rat myometrial cells to lindane or TPA nearly abolished dye transfer but did not alter the electrophoretic mobility of connexin43, and neither lindane nor TPA increased phosphorylation of connexin 43 as assessed by immunoblot with anti-phospho-connexin43 (S368) antibody. However, TPA increased punctate immunofluorescence staining of phospho-connexin43 (S368) in myometrial cells whereas lindane had no such effect. In WB ${ }^{\mathrm{r}}-\mathrm{F} 344$ cells, lindane and TPA inhibited dye transfer. Lindane increased immunostaining for phospho-connexin 43 (S368) in $\mathrm{WB}^{\mathrm{r}}$ F344 cells without altering the abundance, electrophoretic mobility or phosphorylation of connexin 43 as detected in immunoblots. TPA intensified a slower migrating connexin 43 band and increased phospho-connexin43 (S368) in immunoblots, and intensified phospho-connexin43 immunostaining at $\mathrm{WB}^{\mathrm{r}}-\mathrm{F} 344$ cell interfaces and nuclear regions. These results show that phosphorylation of connexin 43 at serine 368 occurred in cell and toxicant specific manners and was independent of changes in electrophoretic mobility in standard SDS-PAGE gels. Moreover, lindane inhibited gap junction communication in myometrial cells by a mechanism that was not be explained by changes in phosphorylation of connexin 43 .
\end{abstract}

Abbreviations: CMF-PBS, calcium/magnesium-free phosphate buffered saline; DMSO, dimethyl sulfoxide; PBS-G, phosphate buffered saline supplemented with glucose; PKC, protein kinase C; SDS, sodium dodecyl sulfate; TPA, 12-O-tetradecanoylphorbol-13-acetate

\section{Introduction}

Gap junctions between adjoining cells form an intercellular network that allows direct cell-to- cell transfer of low molecular weight $(<1000$ Da) molecules. Connexons are hemichannels in cell membranes that join together from adjacent cells to form the continuous trans- 
membrane aqueous channels of the gap junction. Each connexon is composed of six connexin proteins, and a family of connexins exists (Evans and Martin, 2002). The most widely expressed connexin is connexin43, found in tissues such as skin, endothelium, heart, and uterus (Evans and Martin, 2002). Mutations of connexins are linked to congenital cataracts, deafness, nervous system disorders, and skin diseases (Evans and Martin, 2002). Phosphorylation may regulate the function and processing of connexins by multiple mechanisms, including PKC-regulated (Lampe and Lau, 2000) and ERK-regulated (Mograbi et al., 2003) phosphorylation of connexin 43.

In the uterus during pregnancy, up-regulation of connexin 43 and subsequent increased abundance of gap junctions promote parturition by allowing coordinated contractions of increased force (Garfield and Hayashi, 1981; Garfield et al., 1977; Lefebvre et al., 1995; Orsino et al., 1996; Ou et al., 1997; Risek et al., 1990). Our laboratory previously showed that the organochlorine pesticide lindane $(\gamma-$ hexachlorocyclohexane) inhibits uterine contractions in muscle baths (Criswell and LochCaruso, 1999; Krieger and Loch-Caruso, 2001; Wang and Loch-Caruso, 2002) and gap junction intercellular communication in rat myometrial cells (Criswell et al., 1995). Because connexin43 is a phosphoprotein (Musil et al., 1990) and lindane activates PKC in rat myometrial cells (Criswell et al., 1995), it was suggested that lindane may inhibit gap junction communication between myometrial cells by PKC-mediated phosphorylation of connexin43 (Criswell et al., 1995).

The present study examines the hypothesis that lindane-induced inhibition of gap junction communication between myometrial cells requires phosphorylation of connexin 43 . The phorbol ester 12-O-tetradecanoylphorbol-13acetate (TPA) and rat liver $\mathrm{WB}^{\mathrm{r}}$-F344 cells were included in the experiments to permit comparison of cells and compounds, and to provide positive controls. TPA was the first tumor promoter identified as an inhibitor of gap junctions (Murray and Fitzgerald, 1979; Yotti et al., 1979), is a potent synthetic activator of PKC (Castagna et al., 1982; Nishizuka, 1986), and has been shown to increase phosphorylation of connexin43 (Berthoud et al., 1992, 1993; Godwin et al., 1993).

\section{Materials and methods}

\section{Chemicals}

Lindane (99\% purity) was obtained from Sigma Chemical Co. (St. Louis, MO). Type II collagenase, type III trypsin, deoxyribonuclease I, TPA, $\beta$-mercaptoethanol and propidium iodide were also obtained from Sigma. The dye Lucifer yellow (lithium salt) was obtained from Molecular Probes (Eugene, OR). Myometrial cells were cultured in RPMI medium obtained from Gibco BRL (Grand Island, NY). Acrylamide was purchased from Bio-Rad Laboratories (Hercules, CA). Alphasmooth muscle actin monoclonal antibody was obtained from Sigma and goat anti-mouse IgG FITC-conjugated antibody was obtained from Jackson ImmunoResearch Laboratories (West Grove, PA). Alkaline phosphatase was obtained from Boehringer Mannheim (distributed by Roche, Indianapolis, IN).

WB $^{\mathrm{r}}-\mathrm{F} 344$ cells were cultured in a special preparation of Eagle's modified minimum essential medium obtained from Gibco BRL, which contained $1 \times$ Earle's salts, $2 \times$ nonessential amino acids, $1.5 \times$ essential amino acids (except $\mathrm{L}$-glutamine), $1.5 \times$ vitamins, 1 $\mathrm{mmol} / \mathrm{L}$ sodium pyruvate, $5.6 \mathrm{mmol} / \mathrm{L} \mathrm{D}$ glucose, $14.3 \mathrm{mmol} / \mathrm{L}$ sodium chloride, and $11.9 \mathrm{mmol} / \mathrm{L}$ sodium bicarbonate. The medium was supplemented with $10 \%$ bovine calf serum (BCS; HyClone, Logan, UT).

Stock solutions of lindane and TPA were prepared in dimethyl sulfoxide (DMSO) or 
ethanol, respectively, and added to the medium in volumes of $1 \mathrm{ml}$ stock $/ \mathrm{ml}$ medium. Solvent control cultures received $1 \mathrm{ml}$ solvent $/ \mathrm{ml} \mathrm{med-}$ ium. Different stock solutions of TPA and lindane were prepared to maintain constant concentrations of solvent with different concentrations of test compound in the experiments. TPA stock solutions were stored at $10^{\circ} \mathrm{C}$ and lindane stock solutions were stored at $4^{\circ} \mathrm{C}$.

\section{Cell culture}

Myometrial smooth muscle cells were isolated from midgestation (day 10) Sprague-Dawley rats by methods previously described (Caruso et al., 1990). Briefly, on day 10 of pregnancy rats were anesthetized with ether, and uteri were excised and placed in calcium/magnesium-free Hank's balanced salt solution. After removal of ovaries, adipose tissue and cervix, the tissue was minced, then digested for $45 \mathrm{~min}$ at $37^{\circ} \mathrm{C}$ with an enzymatic mixture containing $150 \mu \mathrm{g} / \mathrm{ml}$ type II collagenase, $150 \mu \mathrm{g} / \mathrm{ml}$ type III trypsin, and $100 \mu \mathrm{g} / \mathrm{ml}$ deoxyribonuclease I. The digest was filtered through doublelayered cheesecloth, centrifuged twice with RPMI medium, and seeded into $75-\mathrm{cm}^{2}$ flasks containing growth medium. The smooth muscle character of the cells was verified with indirect immunofluorescence labeling with anti-a-smooth muscle actin monoclonal antibody as previously described and exceeded 99\% (Caruso et al., 1990). Previous studies indicate that these cells express connexin43 but not connexin32 (Caruso et al., 1990).

The WB ${ }^{\mathrm{r}}-\mathrm{F} 344$ cell line was derived from the original rat liver WB-F344 line by selection for resistance to neomycin, and was provided as a gift by Dr James Trosko (Michigan State University). The original rat liver WB-F344 line was a gift to Dr Trosko from Dr JW Grisham. The WB-F344 cells express connexin43 but not connexin32 or connexin 26 (Ren et al., 1994).
Cells were subcultured as needed to maintain subconfluence, about every 5-7 days, and incubated at $37^{\circ} \mathrm{C}$ in a $5 \% \mathrm{CO}_{2}$ atmosphere. For microinjection experiments, cells at passage 1,2 , or 3 were seeded at a density of $50000-60000$ cells per $60-\mathrm{mm}$ dish $24 \mathrm{~h}$ prior to microinjection. Cells were also seeded in 75$\mathrm{cm}^{2}$ flasks until they were $95-100 \%$ confluent to use in Western blot experiments.

\section{Western blot}

Connexin protein was extracted by hypotonic alkalinization as described previously (Matesic et al., 1994; Ruch et al., 1994). Cells were washed twice with calcium/magnesium-free phosphate buffered saline (CMF-PBS) containing $2.68 \mathrm{mmol} / \mathrm{L} \mathrm{KCl}, 1.50 \mathrm{mmol} / \mathrm{L}$ $\mathrm{K}_{3} \mathrm{PO}_{4}$ (monobasic), $136.9 \mathrm{mmol} / \mathrm{L} \mathrm{NaCl}, 8.1$ $\mathrm{mmol} / \mathrm{L} \mathrm{Na}_{3} \mathrm{PO}_{4}$ (dibasic heptahydrate) at $\mathrm{pH}$ 7.2. Cells were then treated with $375 \mathrm{ml}$ of hypotonic buffer $(10 \mathrm{mmol} / \mathrm{L}$ Tris- $\mathrm{HCl}$ at $\mathrm{pH}$ $7.5,1 \mathrm{mmol} / \mathrm{L}$ aminobenzenesulfonylfluoride, $10 \mathrm{mmol} / \mathrm{L}$ iodoacetamide), alkalinized with $550 \mathrm{ml}$ of $40 \mathrm{mmol} / \mathrm{L} \mathrm{NaOH}$, sonicated with 10 -s pulses from a probe sonicator, and centrifuged at $4^{\circ} \mathrm{C}$ for $30 \mathrm{~min}$ at $15000 \mathrm{~g}$. The pellet was resuspended and solubilized in a buffer containing $62.5 \mathrm{mmol} / \mathrm{L}$ Tris $(\mathrm{pH} 6.8)$, $2 \%$ sodium dodecyl sulfate (SDS), and 10\% glycerol. Protein was solubilized by brief sonication with 10-s pulses from a probe sonicator. Samples were centrifuged at $4^{\circ} \mathrm{C}$ for $5 \mathrm{~min}$ at $15000 \mathrm{~g}$. Protein content was determined in supernatants with the DC protein assay (BioRad Corp., Richmond, CA). Equal amounts of protein $(25 \mathrm{mg})$ were separated by electrophoresis on $10 \%$ SDS-polyacrylamide gels under reducing conditions and blotted electrophoretically to Immobilon-P membranes (Millipore Corp., Bedford, MA). Connexin43 protein was detected by incubating the membranes overnight with anti-connexin43 rabbit polyclonal antibody (Zymed Laboratories, Inc., San Francisco, CA) in a 1:2000 
dilution, followed by incubation with antirabbit Ig, peroxidase-linked antibody (Amersham Corp., Arlington Heights, IL) in a 1:10000 dilution. Antibody localization was determined with an Enhanced Chemi-Luminescence detection kit (ECL Kit, Amersham Corp.) following manufacturer's directions. Kaleidoscope Prestained Molecular Weight standards (Bio-Rad Laboratories, Hercules, CA) were included in each Western blot. The intensity of each connexin43-immunoreactive band was quantified by densitometry using Un-Scan-It software (Silk Scientific Corp., Orem, UT), and the intensities of the connexin43 bands were summed for each lane. To assess redistribution of connexin 43 among the four possible gel bands and control for possible differences due to unequal gel loading, protein integrity and protein expression, the density of each connexin43 band was expressed as the proportion of total density of connexin43immunoreactive bands within each lane. To evaluate changes in connexin 43 abundance, the densities of all bands in a lane were summed to determine total immunostaining of connexin43, and expressed as the proportional change in density relative to solvent controls.

A similar protocol was used to detect phosphorylated connexin43, except that membranes were incubated for $1 \mathrm{~h}$ with phosphoconnexin43 (S368) antibody (Cell Signaling Technology Inc., Beverly, MA) in a 1:1000 dilution. Only a single band was detected by lane scan densitometry, and these values were expressed as the proportional change in density relative to solvent controls.

\section{Alkaline phosphatase treatment}

$\mathrm{WB}^{\mathrm{r}}-\mathrm{F} 344$ cells were treated with $50 \mathrm{nmol} / \mathrm{L}$ TPA, $0.1 \%$ ethanol (solvent control) or left untreated for $1 \mathrm{~h}$. The protein was collected and diluted four-fold in a buffer containing $62.5 \mathrm{mmol} / \mathrm{L}$ Tris ( $\mathrm{pH} 6.8$ ), $2 \%$ sodium dode- cyl sulfate (SDS) and 10\% glycerol. The samples were then split and half were treated with $8 \mathrm{U}$ alkaline phosphatase $/ 10 \mathrm{mg}$ protein for 30 min before proceeding with the Western blot.

\section{Microinjection of Lucifer yellow}

Myometrial cells were individually microinjected with a mixed dye solution of $0.8 \%$ Lucifer yellow and $0.02 \%$ propidium iodide in CMF-PBS as previously described (Criswell et al., 1995). Lucifer yellow, a hydrophilic fluorescent dye with a low molecular weight, was used to monitor gap junction communication. Propidium iodide rapidly reacted with nuclear DNA and served as a marker of the injected cell. Medium was replaced with phosphate buffered saline $\left(0.9 \mathrm{mmol} / \mathrm{L} \mathrm{CaCl}_{2}, 2.68\right.$ $\mathrm{mmol} / \mathrm{L} \mathrm{KCl}, 1.47 \mathrm{mmol} / \mathrm{L} \mathrm{K}_{3} \mathrm{PO}_{4}$ (monobasic), $0.5 \mathrm{mmol} / \mathrm{L} \mathrm{MgCl}_{2}$ (hexahydrate), and 8 $\mathrm{mmol} / \mathrm{L} \mathrm{Na}_{3} \mathrm{PO}_{4}$ (dibasic heptahydrate)) supplemented with $5 \mathrm{mmol} / \mathrm{L}$ glucose (PBS-G) before microinjection of the cell. Both lindane and TPA were present in the PBS-G solution during injection of the exposed cells. Dye was injected into a single cell of a group of 3-6 cells in subconfluent cultures. An injection pressure of 6.5 psi for $200 \mathrm{~ms}$ was used for each injection. Dishes were incubated with lindane, TPA or solvent (controls) for different exposure times prior to microinjection. The number of dishes per group was 9 to 12 and the number of injections per dish was 7 to 12 . Gap junction communication was determined by visual examination 5-10 min after injection with an epifluorescence microscope (Nikon Diaphot) for Lucifer yellow dye fluorescence in cells adjacent to and in direct contact with the injected cell. Dye transfer was quantified as follows:

$$
\% \text { Dye transfer }=\frac{\begin{array}{c}
\text { (\# adjoining cells with } \\
\text { Lucifer yellow fluorescence) }
\end{array}}{\text { total \# of adjoining cells }} \times 100
$$


Immunolocalization of phosphorylated (S368) connexin43

Myometrial cells and $\mathrm{WB}^{\mathrm{r}}$-F344 cells (passage 2) were grown on glass cover slips and incubated with lindane, TPA or solvent (controls) for different exposure times prior to immunofluorescence detection. Following treatment, the cells were washed two times with CMFPBS and fixed in 4\% paraformaldehyde in 0.1 $\mathrm{mol} / \mathrm{L}$ sodium cacodylate at $\mathrm{pH} 7.4$ for $30 \mathrm{~min}$ at room temperature. Following a $10-\mathrm{min}$ permeablization in methanol, the cells were blocked for $30 \mathrm{~min}$ at room temperature in $5 \%$ normal goat serum and incubated overnight at $4{ }^{\circ} \mathrm{C}$ with anti-phospho-connexin 43 (S368) antibody (1:1000) (Cell Signaling Technology). Afterwards, cells were treated with an anti-rabbit IgG AlexaFluor 488 (Molecular Probes, Cat A-11008) for $1 \mathrm{~h}$ and mounted on slides. Immunofluorescence was observed and recorded with an Olympus AX-70 fluorescent microscope.

\section{Statistical analysis}

The results are expressed as the mean \pm SEM. Data analyses were conducted using SigmaStat (Jandel Scientific Software, San Rafael, CA) or Prism (GraphPad Software, Inc. San Diego, CA) software. Because of the nonparametric nature of percentile and proportional data, dye transfer data and Western blot densitometry data were analyzed by Kruskal-Wallis oneway analysis of variance on ranks. The pairwise post-hoc comparisons of groups for the dye transfer data from rat myometrial cells exposed to TPA were by Dunnett's method. All other post-hoc comparisons of groups with solvent controls were by Dunn's method. A $p$ value of $\leqslant 0.05$ was considered significant.

\section{Results}

Inhibition of Lucifer yellow dye transfer

The effects of lindane and TPA on gap junction intercellular communication were studied by monitoring intercellular transfer of the fluorescent dye Lucifer yellow. Treatment with lindane inhibited dye transfer between myometrial cells (Figure 1A; Kruskal-Wallis, $p<0.001)$. Exposure to $50 \mu \mathrm{mol} / \mathrm{L}$ lindane reduced dye transfer in rat myometrial cells from $96.8 \pm 1.3 \%$ in the solvent (DMSO) controls to $0.3 \pm 0.3 \%$ after $0.5 \mathrm{~h}$ treatment (Figure $1 \mathrm{~A} ; p \leqslant 0.05)$. Dye transfer remained inhibited at $3.8 \pm 1.5 \%$ after a $4-\mathrm{h}$ exposure to $50 \mu \mathrm{mol} / \mathrm{L}$ lindane (Figure $1 \mathrm{~A} ; p \leqslant 0.05$, significantly different from control). Likewise, TPA inhibited dye transfer in rat myometrial cells (Figure 1B; Kruskal-Wallis, $p<0.001)$. Dye transfer decreased from $97.4 \pm 0.8 \%$ in the solvent (ethanol) controls to $10.3 \pm 1.3 \%$ and $7.5 \pm 0.9 \%$ in cultures treated with $16 \mathrm{nmol} / \mathrm{L}$ or $50 \mathrm{nmol} / \mathrm{L}$ TPA, respectively, after exposure for $0.5 \mathrm{~h}$ (Figure 1B; $p \leqslant 0.05$, significantly different from control). Exposure to $50 \mathrm{nmol} /$ L TPA for $4 \mathrm{~h}$ inhibited dye transfer to $16.1 \pm 1.7 \%$ (Figure 1B; $p \leqslant 0.05$, significantly different from control). These data show that lindane and TPA rapidly inhibited Lucifer yellow dye transfer between myometrial cells in culture.

Consistent with previous reports (Guan et al., 1995; Matesic et al., 1994; Oh et al., 1993), dye transfer was inhibited in WB $^{\mathrm{r}}-\mathrm{F} 344$ cells treated with lindane (Figure 2A; KruskalWallis, $p<0.001$ ) or TPA (Figure 2B; Kruskal-Wallis, $p<0.001)$. Dye transfer initially decreased from $96.7 \pm 0.8 \%$ in the controls to $11.7 \pm 2.2 \%$ after a 0.5 -h treatment with 50 $\mu \mathrm{mol} / \mathrm{L}$ lindane $(p \leqslant 0.05$; Figure $2 \mathrm{~A})$. This inhibition partially reversed in the continued presence of $50 \mu \mathrm{mol} / \mathrm{L}$ lindane, with cells exhibiting $35.5 \pm 3.1 \%$ dye transfer after $4 \mathrm{~h}$ of treatment $(p \leqslant 0.05$, significantly different from 
A

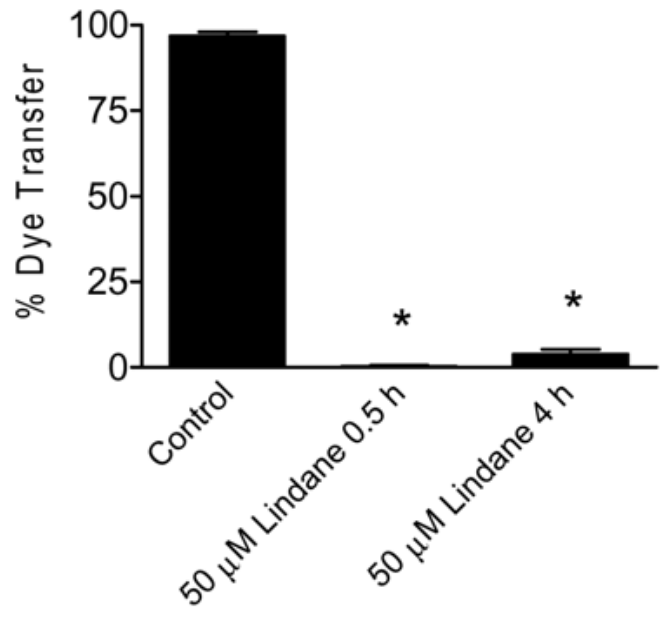

B

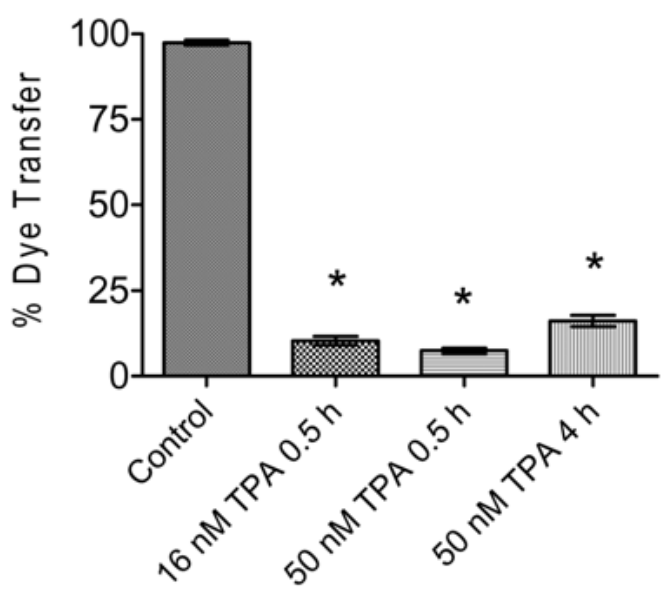

Figure 1. A: Inhibition of Lucifer yellow dye transfer in rat myometrial cell cultures exposed to $50 \mu \mathrm{mol} / \mathrm{L}$ lindane for $0.5 \mathrm{~h}$ or $4 \mathrm{~h}$. Controls were exposed to $0.1 \%$ DMSO for $4 \mathrm{~h}$. Data were analyzed by Kruskal-Wallis statistic $(p<0.001)$ and Dunn's test for pairwise comparison of means $\left({ }^{*} p \leqslant 0.05\right.$, significant difference from control). B: Inhibition of Lucifer yellow dye transfer in rat myometrial cell cultures by $16 \mathrm{nmol} /$ L TPA for $0.5 \mathrm{~h}, 50 \mathrm{nmol} / \mathrm{L} \mathrm{TPA}$ for $0.5 \mathrm{~h}$, and $50 \mathrm{nmol} / \mathrm{L} \mathrm{TPA}$ for $4 \mathrm{~h}$. Controls were exposed to $0.1 \%$ ethanol for $4 \mathrm{~h}$. Values are expressed as mean \pm SEM $(n=7-12$ injected cells for 9-12 dishes per group). Error bars not visible are too small to be shown graphically. Data were analyzed by Kruskal-Wallis statistic $(p<0.001)$ and Dunnett's test for pairwise comparison of means $\left({ }^{*} p \leqslant 0.05\right.$, significant difference from control).
A

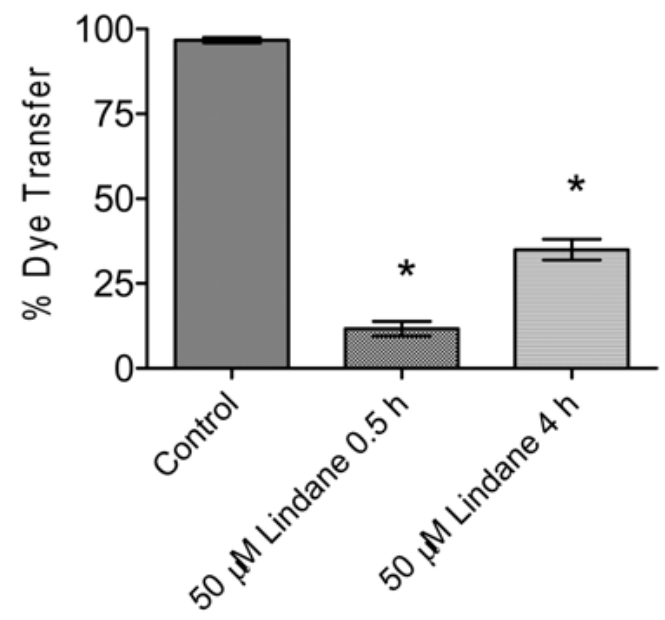

B

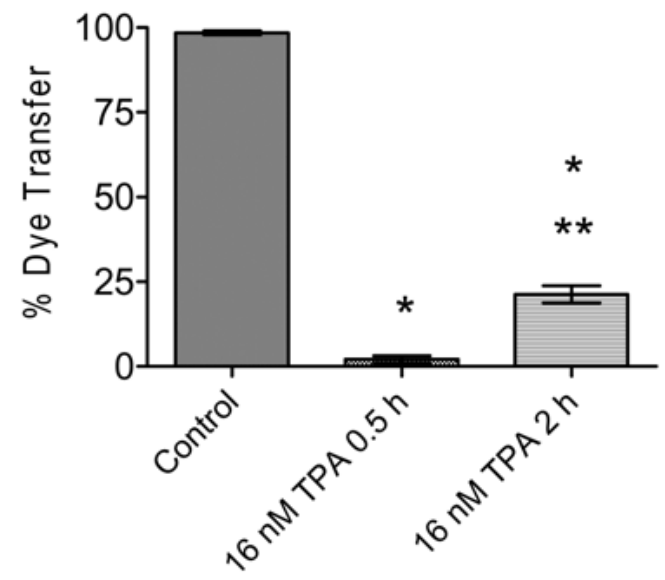

Figure 2. A: Inhibition of Lucifer yellow dye transfer in $\mathrm{WB}^{\mathrm{r}}$ F344 cell cultures exposed to $50 \mu \mathrm{mol} / \mathrm{L}$ lindane for $0.5 \mathrm{~h}$ and 4 h. Data were analyzed by Kruskal-Wallis statistic $(p<0.001)$ and Dunn's test for pairwise comparison of means $\left({ }^{*} p \leqslant 0.05\right.$, significant difference from control). B: Inhibition of Lucifer yellow dye transfer in $\mathrm{WB}^{\mathrm{r}}$-F344 cell cultures exposed to 16 $\mathrm{nmol} / \mathrm{L}$ TPA for $0.5 \mathrm{~h}$ and $4 \mathrm{~h}$. Values are expressed as mean $\pm \operatorname{SEM}(n=7-12$ injected cells for 9-12 dishes per group). Data were analyzed by Kruskal-Wallis statistic and Dunnett's test for pairwise comparison of means $\left(^{*} p \leqslant 0.05\right.$, significant difference from control; ${ }^{* *} p \leqslant 0.05$, significantly different from $0.5 \mathrm{~h}$ treatment). 
control; Figure 2A). TPA exhibited a pattern similar to lindane's pattern of inhibition of dye transfer in $\mathrm{WB}^{\mathrm{r}}$-F344 cells (Figure 2B). Dye transfer initially decreased from $98.5 \pm 0.6 \%$ in the controls to $2.1 \pm 1.1 \%$ in cells treated with $16 \mathrm{nmol} / \mathrm{L}$ TPA for $0.5 \mathrm{~h}$, but was $21.3 \pm 2.6 \%$ in cells treated with $16 \mathrm{nmol} / \mathrm{L}$ TPA for $2 \mathrm{~h}$ (Figure 2B; $p \leqslant 0.05$, significant differences compared to control and $0.5 \mathrm{~h}$ TPA). These results verify that lindane and TPA inhibited Lucifer yellow dye transfer in $\mathrm{WB}^{\mathrm{r}}-\mathrm{F} 344$ cells, similar to the inhibition observed in myometrial cells.

\section{Western blotting for connexin43}

Changes in connexin43 expression were analyzed by Western blotting of cell proteins separated by SDS-PAGE. Proteins isolated from myometrial cells displayed two prominent connexin43 immunoreactive bands (Figure $3 \mathrm{~A}$ ). The faster migrating prominent connexin 43 band corresponds to the connexin 43 isoform previously identified as the NP (nonphosphorylated) or P0 band, and the slower migrating band corresponds to the connexin43 P1 band (Musil et al., 1990; Musil and Goodenough, 1991; Solan et al., 2003). Some gels showed slight immunoreactivity at bands corresponding to the higher molecular weight isoforms of connexin43, P2 and P3 (not visible in the examples shown in Figure 3A). Densitometric analysis showed that over $99 \%$ of immunoreactive connexin 43 from rat myometrial cells migrated in the $\mathrm{P} 0$ and $\mathrm{P} 1$ bands regardless of whether the cells were untreated, exposed to $0.1 \%$ DMSO (solvent control), exposed to $50 \mu \mathrm{mol} / \mathrm{L}$ lindane for $0.5,2$ or 4 $\mathrm{h}$, or exposed to $100 \mu \mathrm{mol} / \mathrm{L}$ lindane for $2 \mathrm{~h}$ (Figure 3B-3E).

Similar to lindane, TPA did not significantly alter myometrial connexin43 electrophoretic mobility (Figure 4). The pattern of connexin 43 migration in the gels was comparable for untreated control cells, solvent $(0.1 \%$ ethanol) control cells, and cells exposed to $16 \mathrm{nmol} / \mathrm{L}$ TPA for $1 \mathrm{~h}$ or $50 \mathrm{nmol} / \mathrm{L}$ TPA for $0.5 \mathrm{~h}$, with $98 \%$ or more of immunoreactive connexin 43 migrating as the $\mathrm{P} 0$ and $\mathrm{P} 1$ bands (Figure 3BE). Although about $20 \%$ of connexin 43 migrated as $\mathrm{P} 3$ and $\mathrm{P} 4$ isoforms after exposure to $50 \mathrm{nmol} / \mathrm{L}$ TPA for $4 \mathrm{~h}$, this difference was not statistically significant compared with solvent controls. Consequently, the Western blot data fail to support a band shift to the slower migrating P3 isoform of connexin43 in myometrial cells exposed to either lindane (Figure $3 \mathrm{E}$ ) or TPA (Figure 4E).

Furthermore, Western blotting showed no changes in the WB ${ }^{\mathrm{r}}-\mathrm{F} 344$ connexin 43 band pattern after $1,2,3$, or $4 \mathrm{~h}$ of exposure to 50 $\mu \mathrm{M}$ lindane compared with control $\mathrm{WB}^{\mathrm{r}}-\mathrm{F} 344$ cells that were unexposed or exposed to $0.1 \%$ DMSO (solvent control) (Figure 5). Densitometric analysis indicated that $98 \%$ or more of immunoreactive connexin 43 migrated as the $\mathrm{P} 0$ and P1 isoforms (Figures 5B-5E). Similarly, no changes were observed in limited experiments of $\mathrm{WB}^{\mathrm{r}}-\mathrm{F} 344$ cells exposed to $100 \mu \mathrm{mol} /$ $\mathrm{L}$ lindane for 3 or $4 \mathrm{~h}$ (data not shown). Because of the possibility that lindane's effects on connexin 43 might be rapidly reversible, experiments were performed in which lindane was present during cell lysis, and no changes in protein electrophoretic mobility were observed (data not shown). These results show that lindane produced no changes in the electrophoretic mobility of connexin 43 of $\mathrm{WB}^{\mathrm{r}}-\mathrm{F} 344$ cells.

As a positive control, connexin 43 protein was analyzed from $\mathrm{WB}^{\mathrm{r}}$-F344 cells exposed to TPA. Western blots of WB $^{\mathrm{r}}-\mathrm{F} 344$ cell protein showed a clear change in connexin 43 gel mobility after 30 or $60 \mathrm{~min}$ of exposure to 16 nmol/L TPA (Figure 6A). Denistometric analysis shows that the proportion of connexin 43 migrating as the P3 band was 0.469 at $30 \mathrm{~min}$ and 0.236 at $60 \mathrm{~min}$, significantly increased compared with solvent controls in which the proportion of connexin 43 migrating as the $\mathrm{P} 3$ 


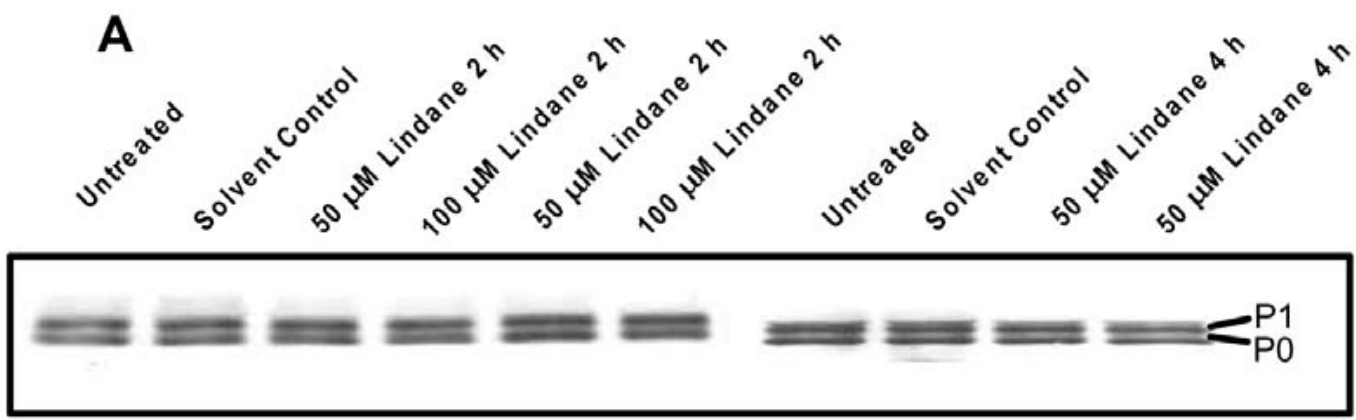

B

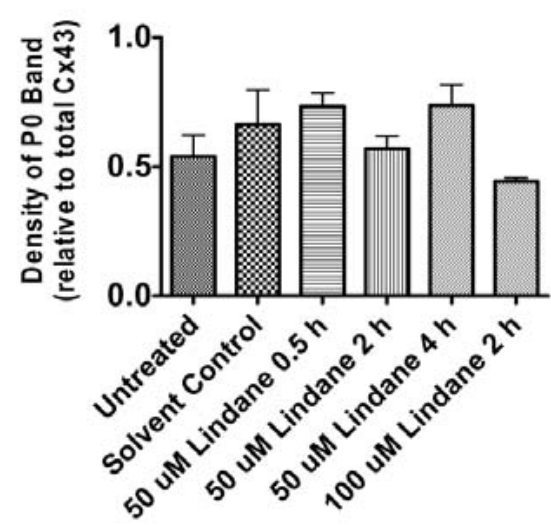

D

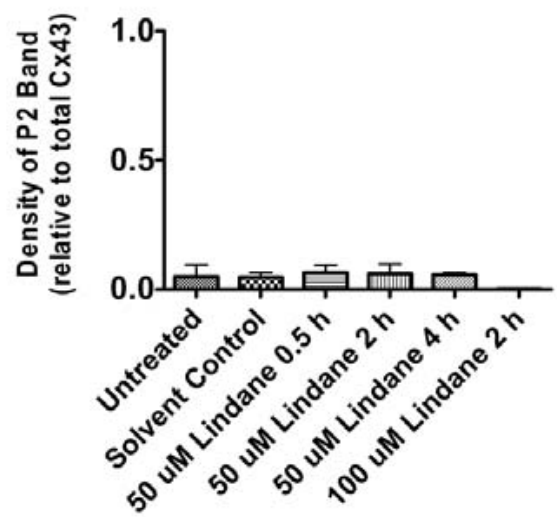

C

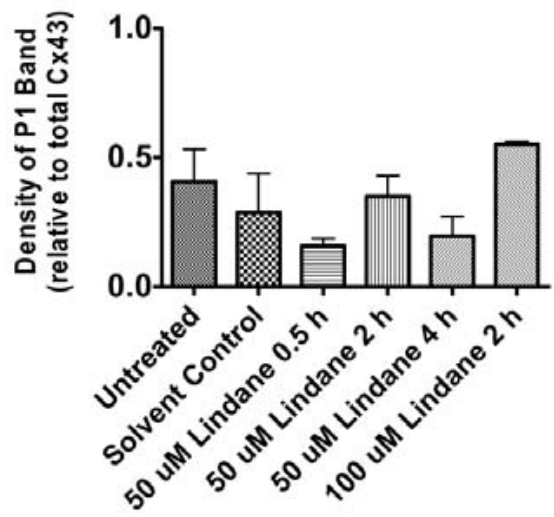

E

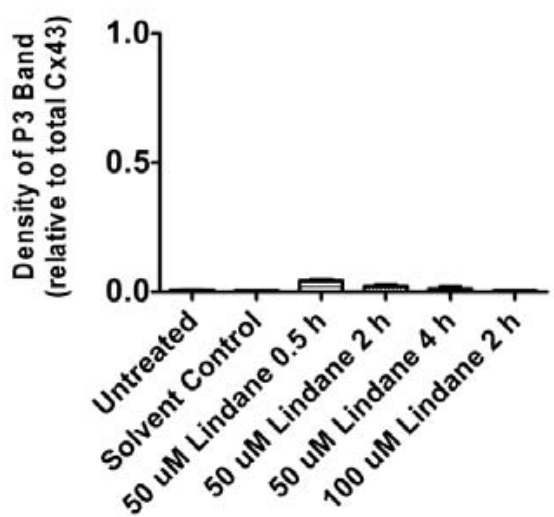

Figure 3. Western blotting of connexin43 protein from rat myometrial cells that were untreated, exposed to $0.1 \%$ DMSO as solvent control, treated with $50 \mu \mathrm{mol} / \mathrm{L}$ lindane for $0.5,2$, or $4 \mathrm{~h}$, or treated with $100 \mathrm{mmol} / \mathrm{L}$ lindane for $4 \mathrm{~h}$. A: Representative western blots showing separation of connexin43 into two bands identified as P0 and P1; the P2 and P3 bands are not visible in the blots shown. B: Density of P0 band. C: Density of P1 band. D: Density of P2 band. E: Density of P3 band. Density values shown are mean \pm SEM of each connexin43 band expressed as the proportion of total density of connexin43-immunoreactive bands within each lane $(n=2-5$ samples per treatment). Error bars not visible are too small to be shown graphically. There were no statistically significant differences between treatment groups for any of the connexin 43 bands. 


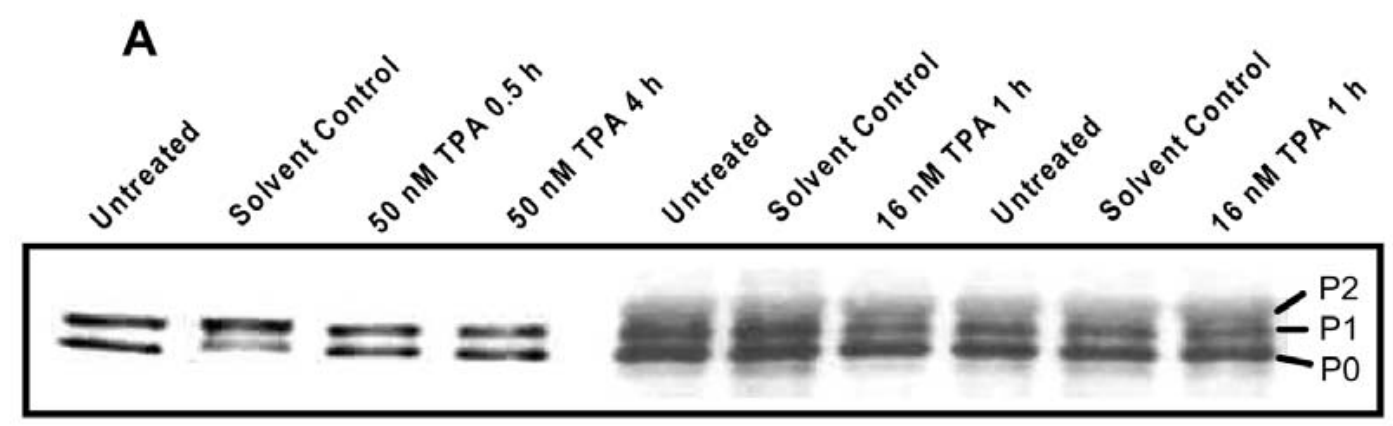

B

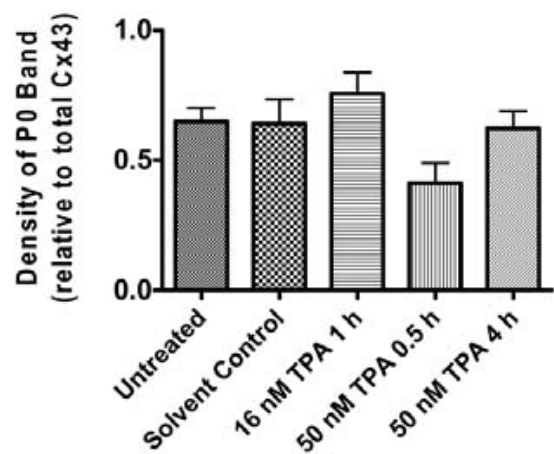

D

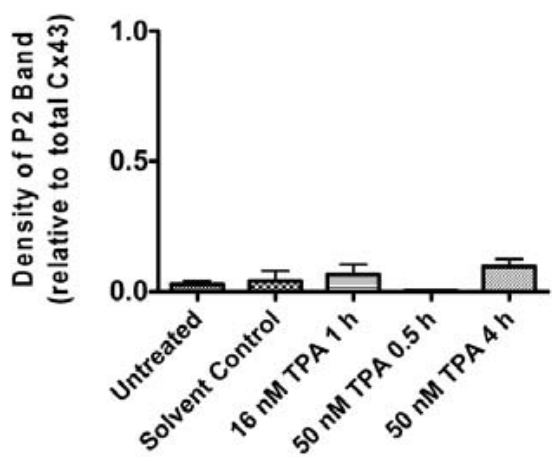

C

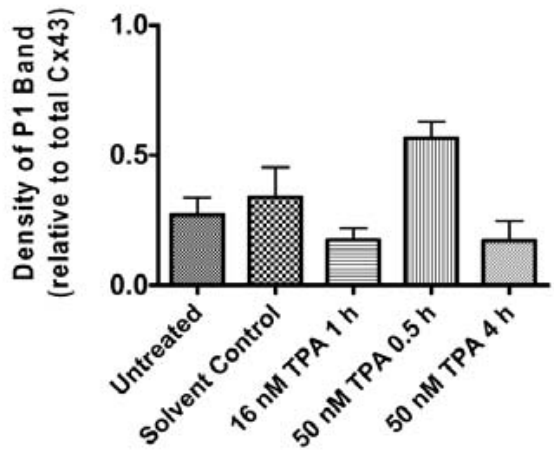

E

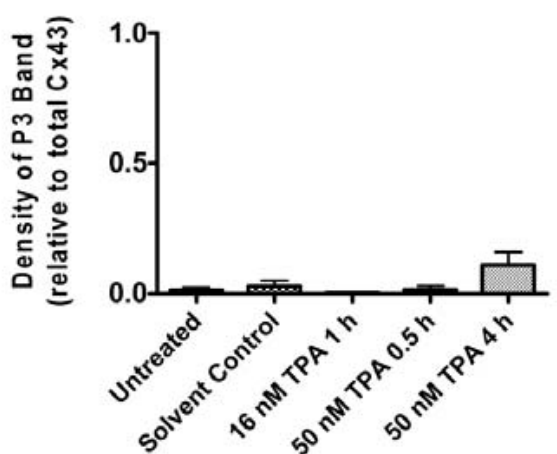

Figure 4. Western blotting of connexin43 protein from rat myometrial cells that were untreated, exposed to $0.1 \%$ ethanol as solvent controls, treated with $16 \mathrm{nmol} / \mathrm{L} \mathrm{TPA}$ for $1 \mathrm{~h}$, or treated with $50 \mathrm{nmol} / \mathrm{L}$ TPA for $0.5 \mathrm{~h}$ or $4 \mathrm{~h}$. A: Representative western blots showing separation of connexin 43 into three bands identified as P0, P1 and P2; the P3 band is not visible in the blots shown. B: Density of P0 band. C: Density of P1 band. D: Density of P2 band. E: Density of P3 band. Density values shown are mean \pm SEM of each connexin 43 band expressed as the proportion of total density of connexin43-immunoreactive bands within each lane $(n=2-6$ samples per treatment). Error bars not visible are too small to be shown graphically. There were no statistically significant differences between treatment groups for any of the connexin 43 bands. 


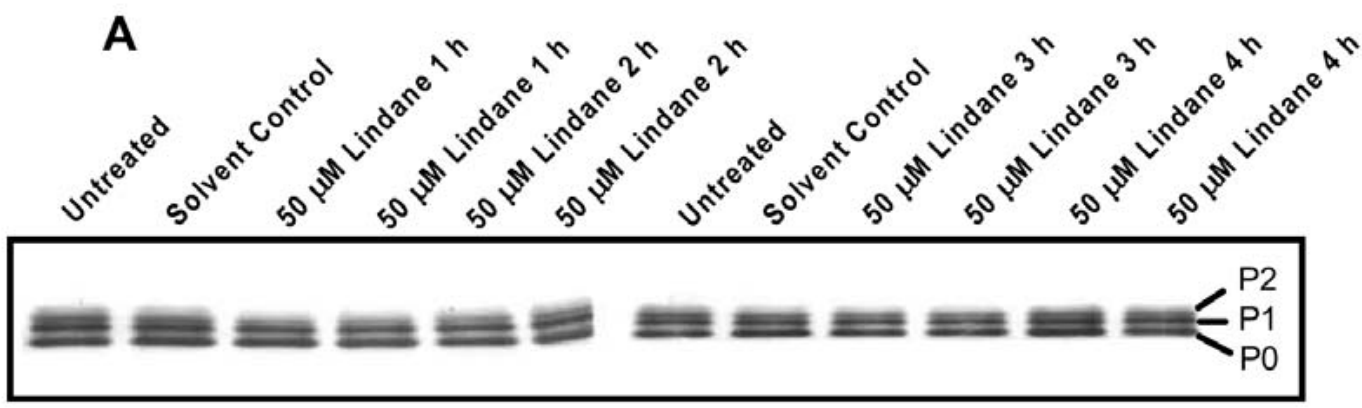

B

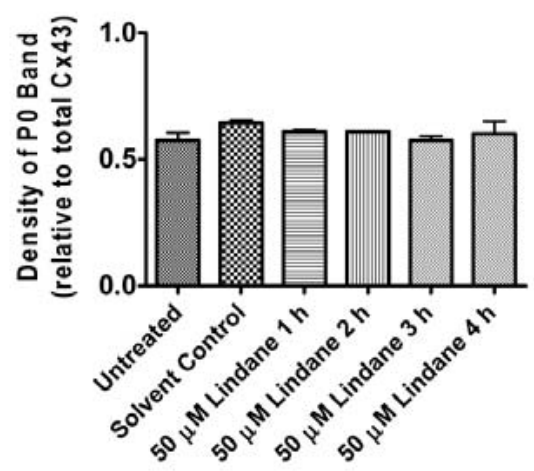

D

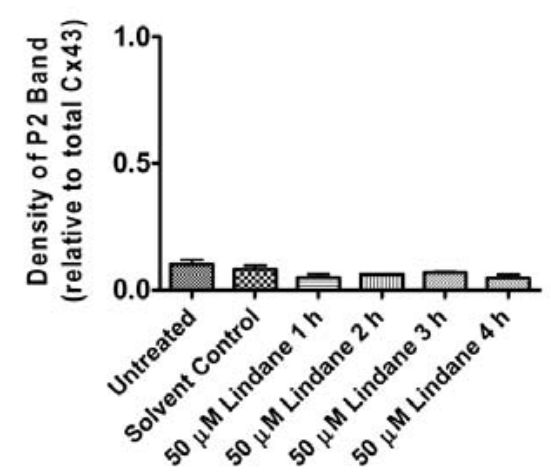

C

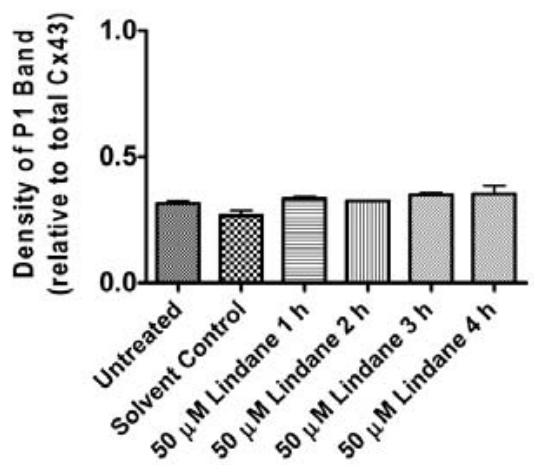

E

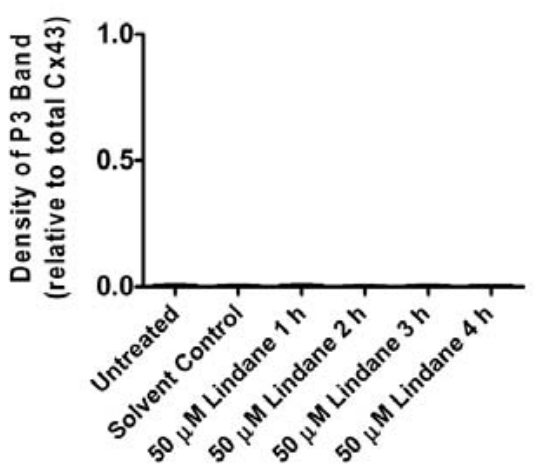

Figure 5. Western blotting of connexin 43 protein from $\mathrm{WB}^{\mathrm{r}}$-F 344 cells that were untreated, exposed to $0.1 \% \mathrm{DMSO}$ as solvent controls, or treated with $50 \mu \mathrm{mol} / \mathrm{L}$ lindane for 1, 2, 3, or $4 \mathrm{~h}$. A: Representative western blots showing separation of connexin 43 into three bands identified as P0, P1, and P2; the P3 band is not visible in the blots shown. B: Density of P0 band. C: Density of P1 band. D: Density of P2 band. E: Density of P3 band. Density values shown are mean \pm SEM of each connexin 43 band expressed as the proportion of total density of connexin43-immunoreactive bands within each lane $(n=2-3$ samples per treatment). Error bars not visible are too small to be shown graphically. There were no statistically significant differences between treatment groups for any of the connexin 43 bands. 
band was 0.024 ( $p \leqslant 0.05$; Figure $6 \mathrm{E})$. The P3 isoform of connexin 43 became less abundant after 100 and $120 \mathrm{~min}$ of exposure to $16 \mathrm{nmol} /$ L TPA, and the densities at these time-points were not significantly different from solvent controls (Figure 6E). In addition, the proportion of connexin 43 migrating as the $\mathrm{P} 1$ band decreased to 0.002 after a 100 -min exposure to $16 \mathrm{nmol} / \mathrm{L}$ TPA, significantly less than solvent controls $(0.017)(p \leqslant 0.05$, Figure 6C). However, the density of the $\mathrm{P} 1$ band did not change in WBr-F344 cells exposed to $16 \mathrm{nmol} / \mathrm{L} \mathrm{TPA}$ for shorter (30 or $60 \mathrm{~min}$ ) or longer durations (120 min) (Figure 6C), nor were statistically significant differences observed in the densities of the $\mathrm{P} 0$ or $\mathrm{P} 2$ bands at any time points (Figure 6B and 6D, respectively). These results demonstrate our ability to detect increased expression of the slower migrating connexin 43 P3 band in WB cells exposed to TPA, as reported by others (Musil et al., 1990). Alkaline phosphatase treatment of protein extracted from untreated $\mathrm{WB}^{\mathrm{r}}-\mathrm{F} 344$ cells or $\mathrm{WB}^{\mathrm{r}}-\mathrm{F} 344$ cells exposed for $1 \mathrm{~h}$ to solvent $(0.1 \%$ ethanol $)$ or $16 \mathrm{nmol} / \mathrm{L}$ TPA eliminated or greatly diminished the P1, P2, and P3 connexin43 bands, as shown in Figure 7, verifying that the slower migrating bands were phosphorylated connexin 43 isoforms.

To assess changes in abundance of connexin43, densities of all four connexin43 bands (P0, P1, P2, and P3) were summed for each sample and expressed as the fold-increase or decrease relative to solvent controls. There were no statistically significant lindane-related or TPA-related changes in total connexin 43 abundance compared with controls for either myometrial or $\mathrm{WB}^{\mathrm{r}}$-F344 cells (Figure 8, controls shown as dashed horizontal line representing a proportional value of 1.0).

Dense bands of connexin43 were observed in heart but not liver proteins, serving as positive and negative controls, respectively (not shown). To verify the specificity of antibody binding, we exposed the primary anti- body to the inhibitor obtained from Zymed Co. (San Francisco, CA). One membrane then was incubated with the rabbit polyclonal anticonnexin 43 and the other membrane with the same antibody previously incubated with the inhibitor. Both membranes had proteins from the same isolation and were incubated under the same conditions. As expected, no bands were present in the presence of the antibody inhibitor (data not shown), confirming the identity of the bands as connexin 43 .

\section{Western blotting for connexin43 phosphorylation} at serine 368

Because Lucifer yellow intercellular dye transfer was inhibited yet no change in connexin 43 electrophoretic mobility was observed for proteins isolated from myometrial cells exposed to lindane or TPA or for proteins isolated from $\mathrm{WB}^{\mathrm{r}}$-F344 cells exposed to lindane, additional Western blot experiments analyzed myometrial proteins for immunoreactivity to an antibody specific for phosphorylation of connexin 43 at serine 368. Proteins isolated from myometrial cells that had been exposed to $0.1 \%$ DMSO (solvent control), $50 \mu \mathrm{mol} / \mathrm{L}$ lindane for $0.5,2$, or $4 \mathrm{~h}$, or $50 \mathrm{nmol} / \mathrm{L}$ TPA for $2 \mathrm{~h}$ exhibited a similar immunoblot pattern: a prominent P1 band, a very low density band at $\mathrm{P} 0(<3 \%$ of total density), and no evidence of P2 and P3 bands immunoreactive with anti-phospho-connexin43 (S368) (Figure 9A and 9B). These results indicate that myometrial connexin 43 was phosphorylated by lindane and TPA at serine 368 , and that the phosphorylated isoform migrated in a manner similar to the P1 isoform. Moreover, phosphorylation of connexin43 at serine 368 did not correspond with the appearance of the slower migrating P3 gel band. To assess changes in the amount phosphorylation of connexin 43 , densities of all phospho-connexin43 (S368) bands were summed and expressed as the fold-increase or decrease relative to solvent controls. All treat- 


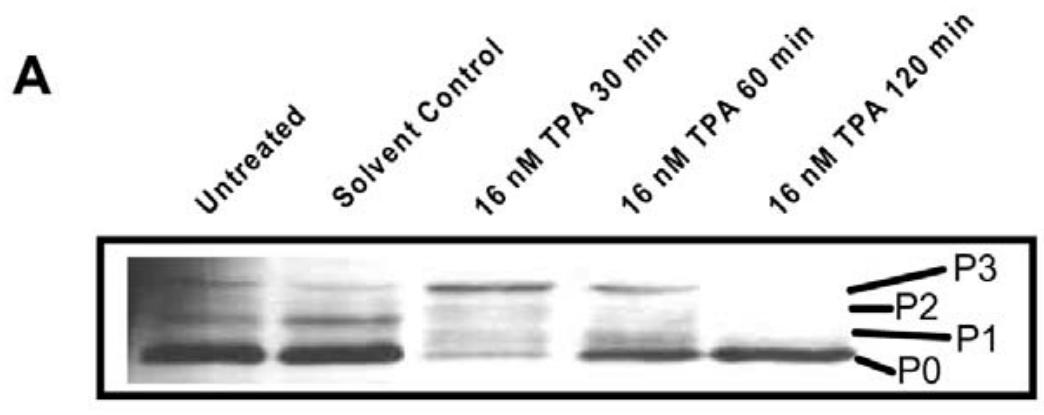

B

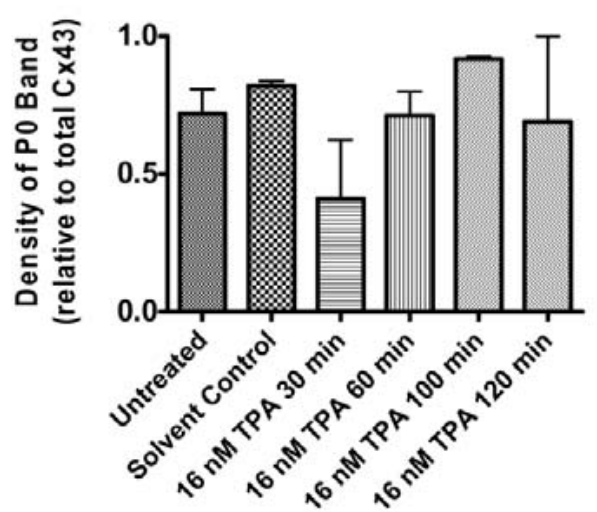

D

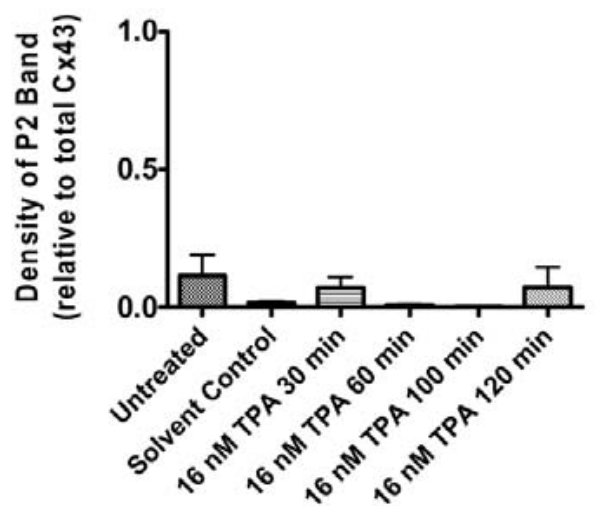

C

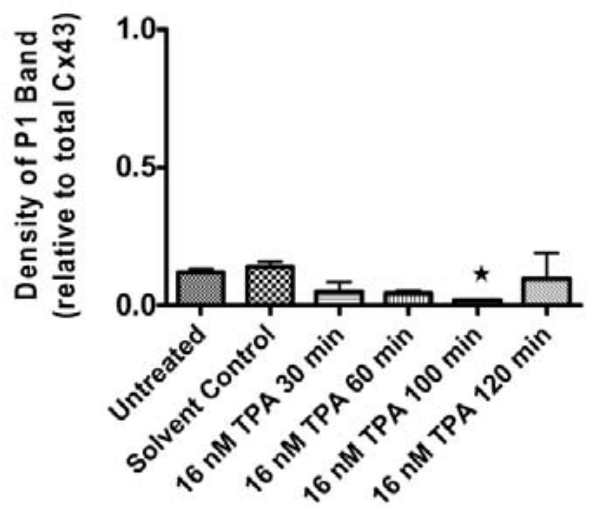

$\mathbf{E}$

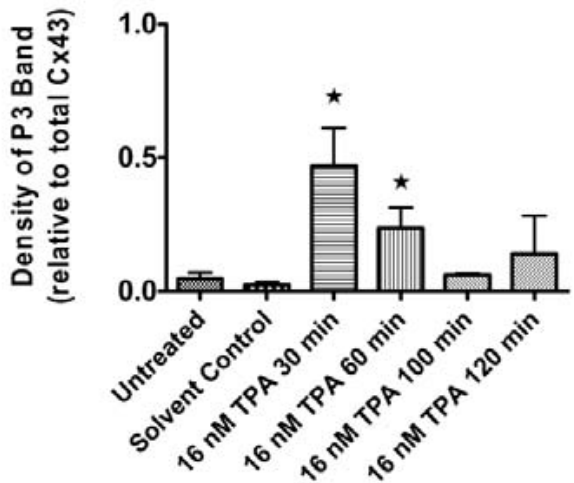

Figure 6. Western blotting of connexin 43 protein from WB ${ }^{\mathrm{r}}$-F 344 cells that were untreated, exposed to $0.1 \%$ ethanol as solvent controls, or treated with $16 \mathrm{nM}$ TPA for 30,60, 100, or $120 \mathrm{~min}$. A: Representative western blots showing separation of connexin43 into four bands identified as P0, P1, P2, and P3 bands. B: Density of P0 band. C: Density of P1 band. D: Density of P2 band. E: Density of P3 band. Density values shown are mean \pm SEM of each connexin 43 band expressed as the proportion of total density of connexin43immunoreactive bands within each lane ( $n=2-3$ samples per treatment). Error bars not visible are too small to be shown graphically. Data were analyzed by Kruskal-Wallis statistic ( $p<0.05$ for P1 and P3 bands) and Dunnett's test for pairwise comparison of means $(* p \leqslant 0.05$, significant difference from control). 


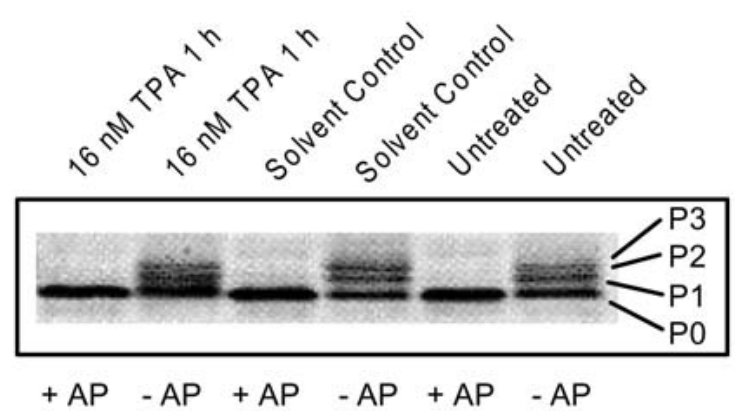

Figure 7. Representative western blot of connexin 43 protein isolated from $\mathrm{WB}^{\mathrm{r}}$-F344 cells that were exposed to $16 \mathrm{nmol} / \mathrm{L}$ TPA for $1 \mathrm{~h}, 0.1 \%$ ethanol for $1 \mathrm{~h}$ (solvent control), or were untreated, and then incubated with $(+)$ or without $(-)$ alkaline phosphatase (AP) before separation by SDS-PAGE. Four connexin43 bands were identified as $\mathrm{P} 0, \mathrm{P} 1, \mathrm{P} 2$, and $\mathrm{P} 3$.

ments reduced the total density of phosphoconnexin43 (S368) bands relative to controls (controls shown as dashed horizontal line representing a proportional value of 1.0 ; $p<0.05$ ), but there were no other statistically significant differences between treatments (Figure 9).

In contrast, $\mathrm{WB}^{\mathrm{r}}$-F344 cells treated with 16 $\mathrm{nmol} / \mathrm{L}$ TPA for $2 \mathrm{~h}$ showed intense immunoreactivity with anti-phospho-connexin 43 (S368) at all four connexin43 bands, such that $31 \%, 7 \%, 21 \%$, and $41 \%$ of phospho-connexin43 migrated as the $\mathrm{P} 0, \mathrm{P} 1, \mathrm{P} 2$ and $\mathrm{P} 3$ bands, respectively (Figures $10 \mathrm{~A}$ and 10B). Treatment with $16 \mathrm{nmol} / \mathrm{L}$ TPA for $2 \mathrm{~h}$ increased phospho-connexin43 (S368) density 1.5-fold relative to controls whereas exposure to $50 \mu \mathrm{mol} / \mathrm{L}$ lindane for $2 \mathrm{~h}$ decreased density by about $9 \%$ relative to controls. In WB ${ }^{\mathrm{r}}-\mathrm{F} 344$ cells that were untreated, exposed to $0.1 \%$ DMSO (solvent control), or exposed to 50 $\mu \mathrm{mol} / \mathrm{L}$ lindane for $2 \mathrm{~h}$, P0 was overwhelmingly the band detected by anti-phosphoconnexin 43 (S368), with $88 \%$ or greater of the total density.

\section{Immunolocalization of phospho-connexin43 (S368)}

Changes in connexin 43 phosphorylation at serine 368 in rat myometrial and WB $^{\mathrm{r}}-\mathrm{F} 344$ cells were analyzed by immunofluorescence imaging in order to visualize any changes in cellular localization. Relatively sparse punctate immunostaining for phosphorylated connexin43 (S368) was observed at cell interfaces and in the nuclear regions of solvent control rat myometrial cells (Figure 11A, B, E, and F). There were no observable changes in the immunofluorescence staining pattern of phospho-connexin43 (S368) after exposure to 50 $\mu \mathrm{mol} / \mathrm{L}$ lindane for $0.5 \mathrm{~h}$ (Figure $11 \mathrm{C}$ ) or $4 \mathrm{~h}$ (Figure 11D) compared with solvent controls exposed to $0.1 \%$ DMSO (Figure $11 \mathrm{~A}$ and B, $0.5 \mathrm{~h}$ and $4 \mathrm{~h}$, respectively). In contrast, the fluorescence pattern of phospho-connexin 43 (S368) staining was intensified in the plasma membrane and nuclear region of myometrial cells exposed to $50 \mathrm{nmol} / \mathrm{L}$ TPA for $0.5 \mathrm{~h}$ (Figure $11 \mathrm{G})$ or $4 \mathrm{~h}$ (Figure $11 \mathrm{H})$ compared with solvent controls exposed to $0.1 \%$ ethanol (Figure 11E and F, $0.5 \mathrm{~h}$ and $4 \mathrm{~h}$, respectively).

As observed in control myometrial cells, $\mathrm{WB}^{\mathrm{r}}$-F344 solvent control cells exhibited sparse punctate immunostaining for phosphorylated connexin43 (S368) (Figure 12A, B, E, F). WB ${ }^{\mathrm{r}}-\mathrm{F} 344$ cells showed an increase in immunofluorescence staining of phospho-connexin43 (S368) at the cell-cell interfaces following exposure to $50 \mu \mathrm{mol} / \mathrm{L}$ lindane for $0.5 \mathrm{~h}$ (Figure 11C) compared with solvent controls exposed to $0.1 \%$ DMSO for $0.5 \mathrm{~h}$ (Figure 12A). However, there were no observable differences in the immunostaining pattern of phospho-connexin43 (S368) in $\mathrm{WB}^{\mathrm{r}}$-F344 cells exposed to $50 \mu \mathrm{mol} / \mathrm{L}$ lindane for $4 \mathrm{~h}$ (not shown) or for $1 \mathrm{~h}$ (Figure 12D), compared with solvent controls exposed to $0.1 \%$ DMSO for 1 $\mathrm{h}$ (Figure 12B), suggesting that phosphorylation of connexin 43 at serine 368 was a transient response in $\mathrm{WB}^{\mathrm{r}}$-F344 cells even in the 
A

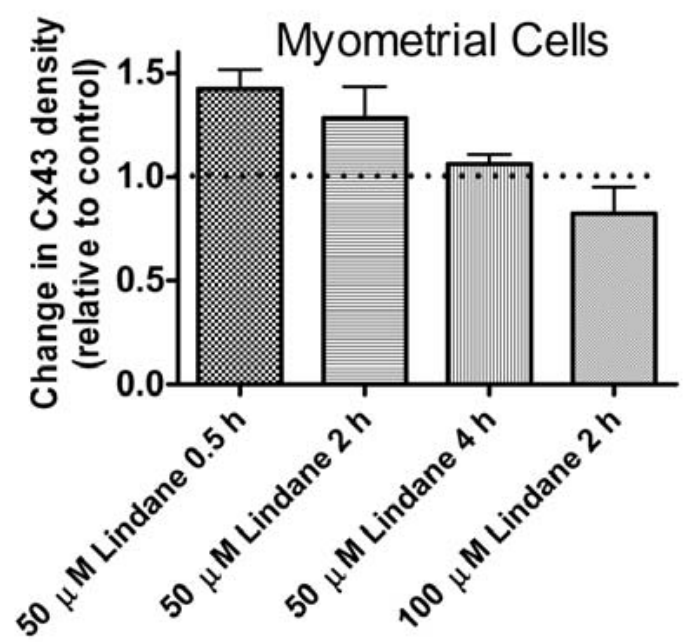

C

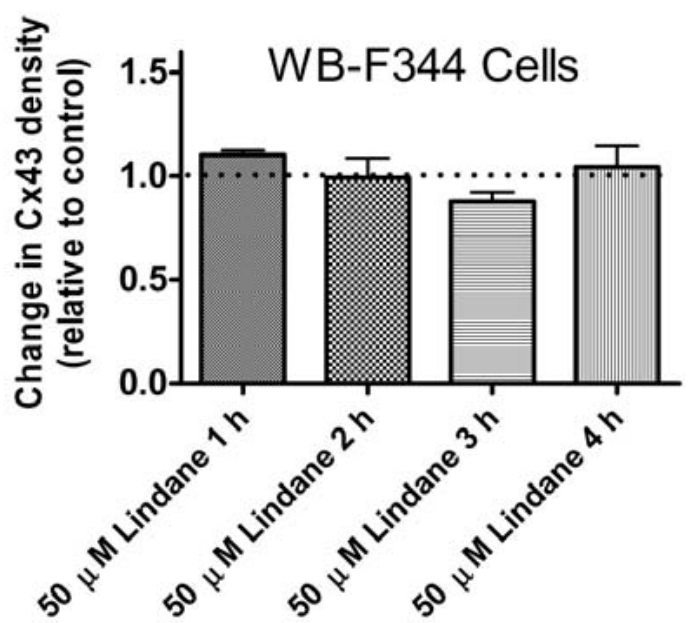

B

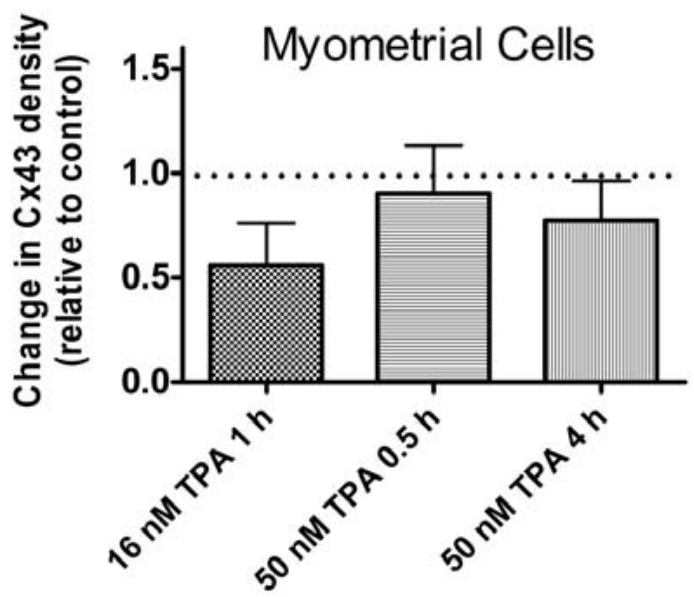

D

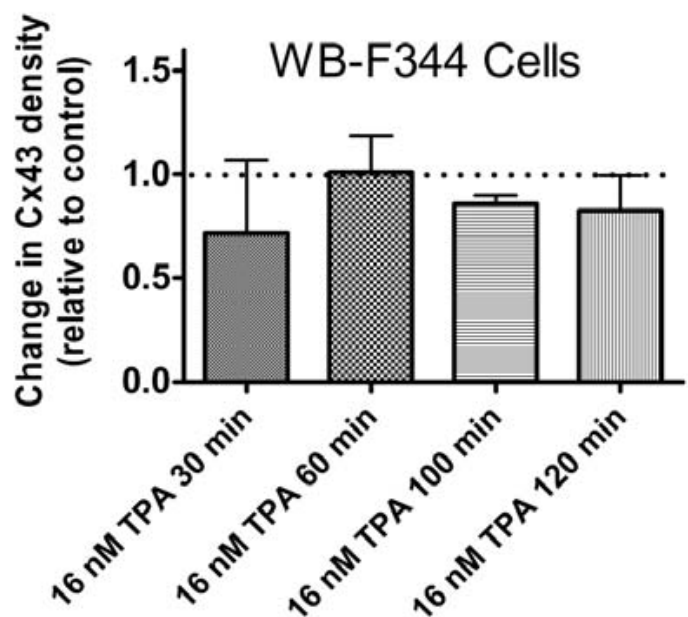

Figure 8. Change of density of connexin43 in immunoblots of SDS-PAGE gels, expressed relative to solvent control (control is depicted in each graph as a dashed horizontal line representing a proportional value of 1.0). A: Myometrial cells exposed to $50 \mu \mathrm{mol} / \mathrm{L}$ lindane for $0.5,2$, or $4 \mathrm{~h}$ or to $100 \mu \mathrm{mol} / \mathrm{L}$ lindane for $2 \mathrm{~h}$. B: Myometrial cells exposed to $16 \mathrm{nmol} / \mathrm{L}$ TPA for $1 \mathrm{~h}$ or $50 \mathrm{nmol} / \mathrm{L}$ TPA for $0.5 \mathrm{~h}$ or 4 h. C: $\mathrm{WB}^{\mathrm{r}}$-F344 cells exposed to $50 \mu \mathrm{mol} / \mathrm{L}$ lindane for $1,2,3$, or $4 \mathrm{~h}$. D: WB ${ }^{\mathrm{r}}-\mathrm{F} 344$ cells exposed to $16 \mathrm{nmol} / \mathrm{L} \mathrm{TPA}$ for 30 , 60 , 100, or $120 \mathrm{~min}$. Values shown represent the mean \pm SEM of 2-6 samples. Treatment means were not statistically significantly different from controls. 


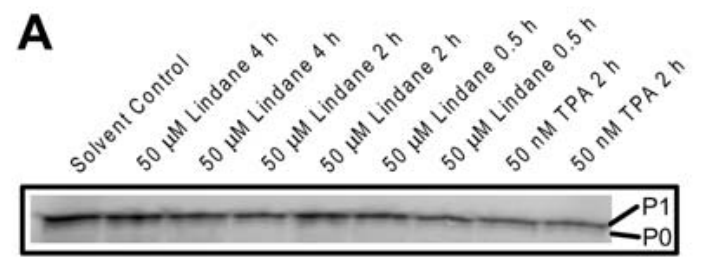

B
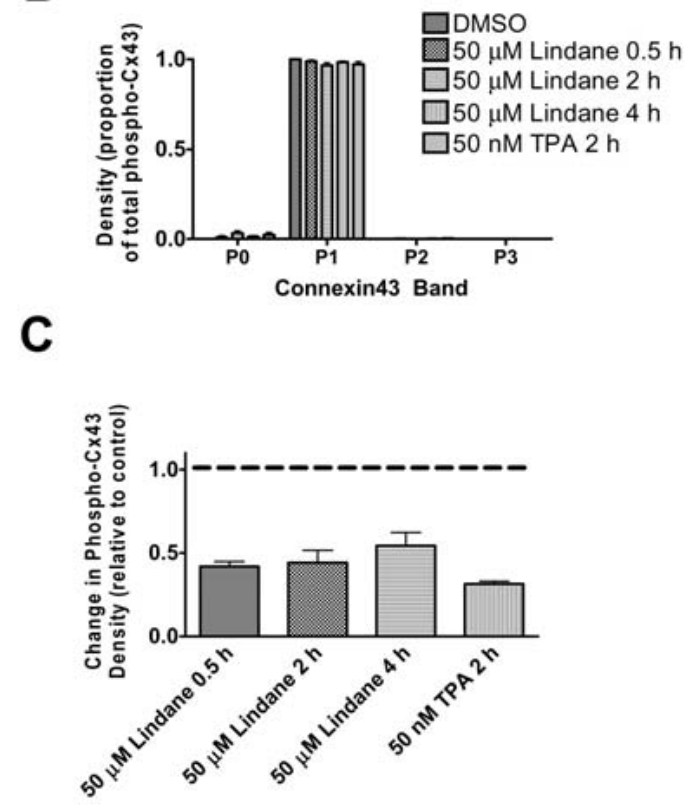

Figure 9. Western blotting of phospho-connexin43 (S368) from myometrial cells exposed to 0.1\% DMSO (solvent controls), 50 $\mu \mathrm{mol} / \mathrm{L}$ lindane for $0.5,2$, or $4 \mathrm{~h}$, or $50 \mathrm{nmol} / \mathrm{L} \mathrm{TPA}$ for $2 \mathrm{~h}$. $\mathbf{A}$ : Representative western blot showing separation of one predominant and one very faint connexin43 band coinciding with the $\mathrm{P} 1$ and $\mathrm{P}$ isoforms, respectively. B: Density of P0, P1, $\mathrm{P} 2$, and P3 bands. Values shown are mean \pm SEM of each connexin43 band expressed as the proportion of total density of connexin43-immunoreactive bands within each lane $(n=4$ samples per treatment). Error bars not visible are too small to be shown graphically. There were no statistically significant differences between treatment groups for any of the connexin43 bands. C: Change of density of phosphoconnexin43 (S368) in immunoblots of SDS-PAGE gels, expressed relative to solvent control (control is depicted in graph as a dashed horizontal line representing a proportional value of 1.0). Values represent mean \pm SEM of 4 samples per treatment.
A

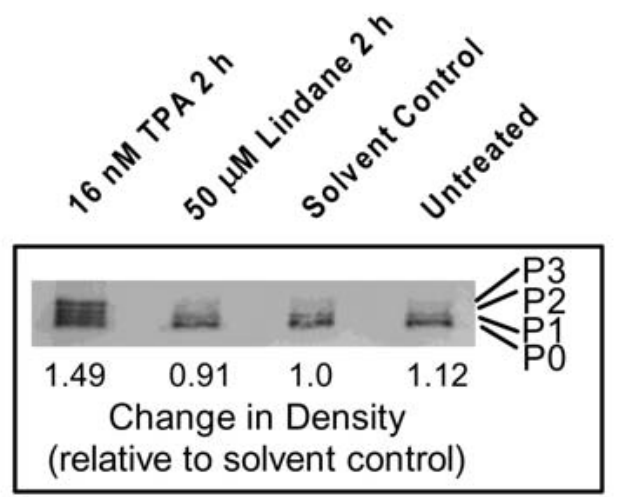

B

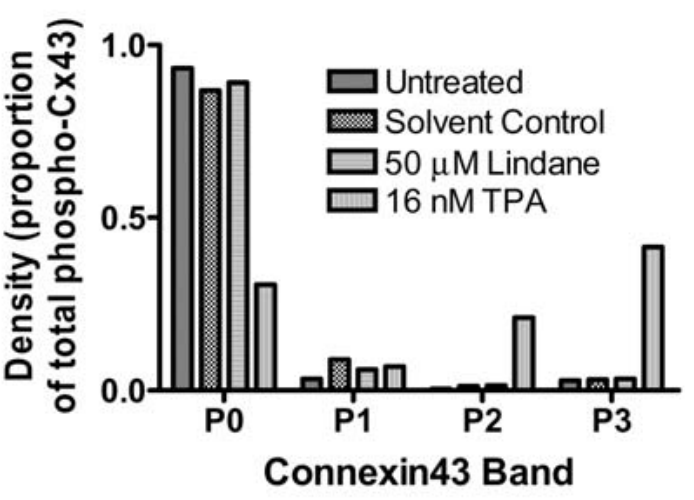

Figure 10. Western blotting of phospho-connexin43 (S368) from $\mathrm{WB}^{\mathrm{r}}$-F344 cells that were untreated or were exposed to $0.1 \%$ DMSO (solvent controls), $16 \mathrm{nmol} / \mathrm{L} \mathrm{TPA}$ for $2 \mathrm{~h}$, or $50 \mu \mathrm{mol} / \mathrm{L}$ lindane for 2 h. A: Western blot showing four distinct bands (P0, P1, P2, and P3) immunoreactive with anti-phosphoconnexin43 (S368). The relative density of the sum of the bands is indicated by the values beneath each lane. B: Density of each band, expressed as the proportion of total phosphoconnexin43 (S368).

continued presence of lindane. A dramatic increase in immunofluorescence staining of phosphorylated connexin43 (S368) was observed in the in the intracellular regions and at the cell-cell interfaces of $\mathrm{WB}^{\mathrm{r}}-\mathrm{F} 344$ cells exposed to $16 \mathrm{nmol} / \mathrm{L}$ TPA for $0.5 \mathrm{~h}$ (Figure $12 \mathrm{G}$ ) and $2 \mathrm{~h}$ (Figure 12H) compared with solvent $(0.1 \%$ ethanol) controls (Figure 12E and $12 \mathrm{~F}, 0.5 \mathrm{~h}$ and $2 \mathrm{~h}$, respectively). Additionally, cells treated with $16 \mathrm{nmol} / \mathrm{L}$ TPA for $2 \mathrm{~h}$ 

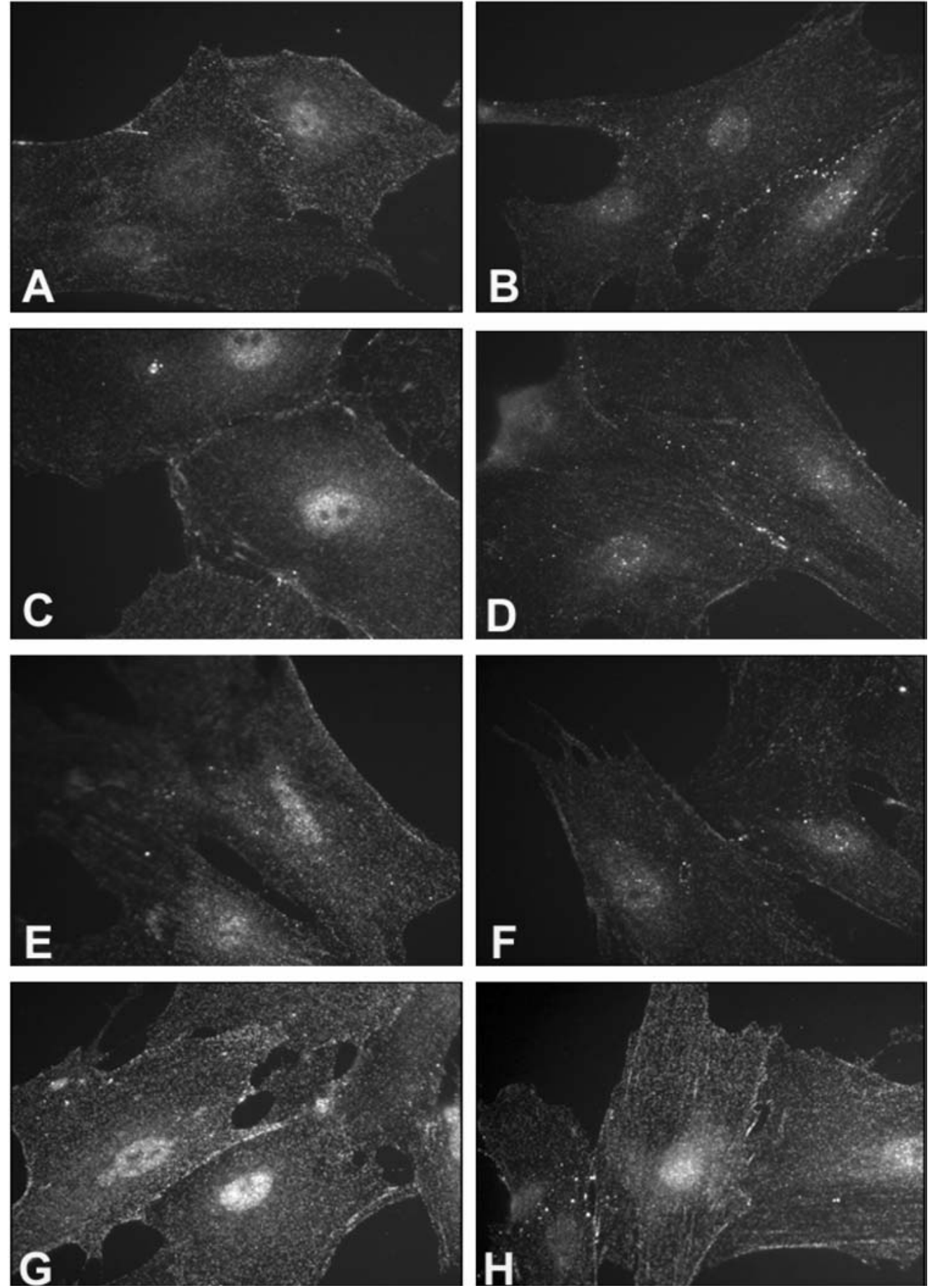

Figure 11. Immunolocalization of phospho-connexin43 (S368) in myometrial cells. A: After exposure to $0.1 \%$ DMSO for $0.5 \mathrm{~h}$ (solvent control for lindane). B: After exposure to $0.1 \%$ DMSO for $4 \mathrm{~h}$ (solvent control for lindane). C: After exposure to $50 \mu \mathrm{mol} / \mathrm{L}$ lindane for $0.5 \mathrm{~h}$. D: After exposure to $50 \mu \mathrm{mol} / \mathrm{L}$ lindane for $4 \mathrm{~h}$. E: After exposure to $0.1 \%$ ethanol for $0.5 \mathrm{~h}$ (solvent control for TPA). F: After exposure to $0.1 \%$ ethanol for $4 \mathrm{~h}$ (solvent control for TPA). G: After exposure to $50 \mathrm{nmol} / \mathrm{L}$ TPA for $0.5 \mathrm{~h}$. $\mathbf{H}$ : After exposure to 50 nmol/L TPA for $0.5 \mathrm{~h}$. All images captured with a $60 \times$ objective. 

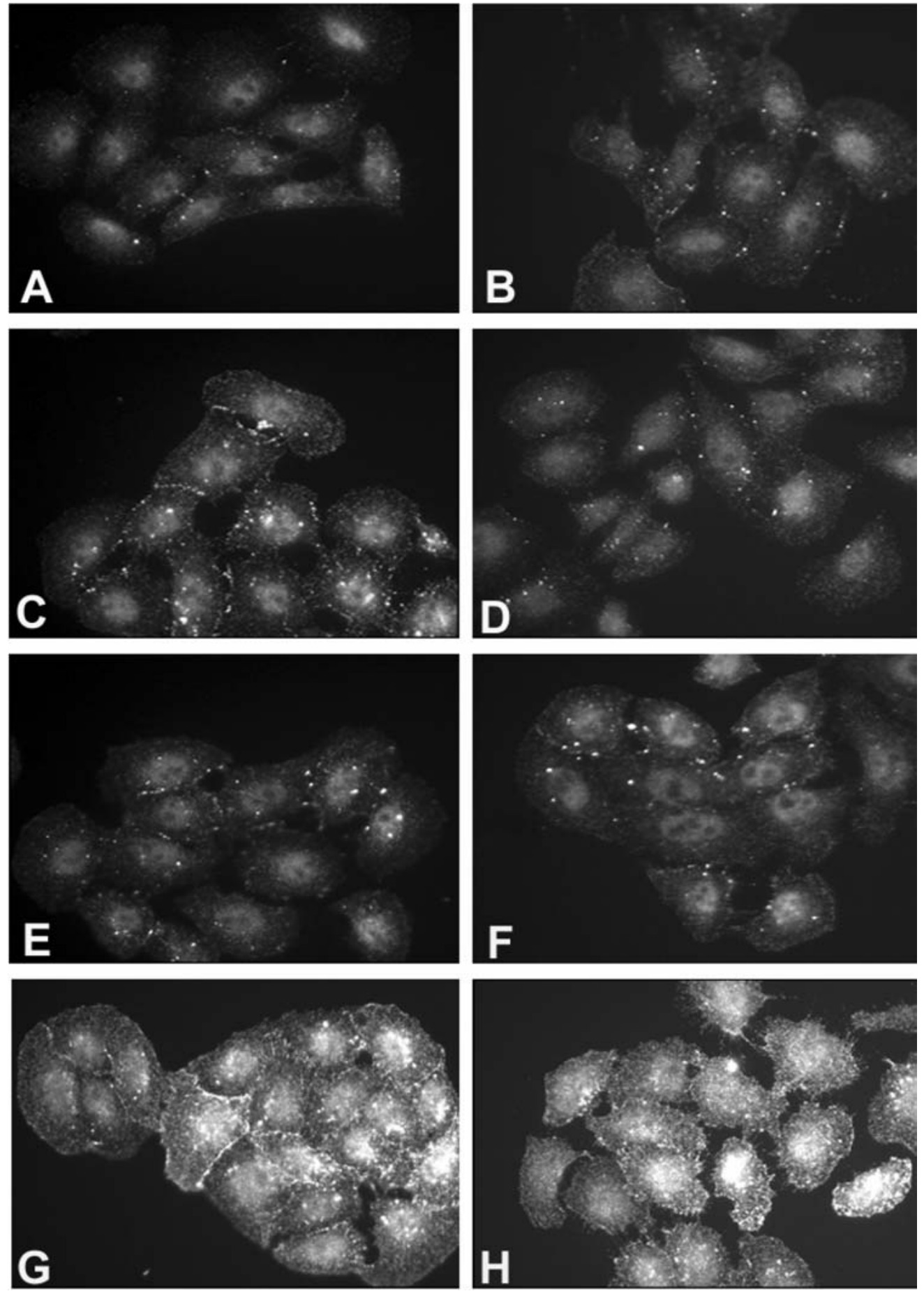

Figure 12. Immunolocalization of phospho-connexin 43 (S368) in WB ${ }^{\mathrm{r}}-\mathrm{F} 344$ cells. A: After exposure to $0.1 \%$ DMSO for $0.5 \mathrm{~h}$ (solvent control for lindane). B: After exposure to $0.1 \%$ DMSO for $4 \mathrm{~h}$ (solvent control for lindane). C: After exposure to $50 \mu \mathrm{mol} / \mathrm{L}$ lindane for $0.5 \mathrm{~h}$. D: After exposure to $50 \mu \mathrm{mol} / \mathrm{L}$ lindane for $4 \mathrm{~h}$. E: After exposure to $0.1 \%$ ethanol for $0.5 \mathrm{~h}$ (solvent control for TPA). F: After exposure to $0.1 \%$ ethanol for $4 \mathrm{~h}$ (solvent control for TPA). G: After exposure to $16 \mathrm{nmol} / \mathrm{L}$ TPA for $0.5 \mathrm{~h}$. $\mathbf{H}$ : After exposure to 16 $\mathrm{nmol} / \mathrm{L}$ TPA for $4 \mathrm{~h}$. All images captured with a $60 \times$ objective. 
exhibited fewer cell-cell contacts, somewhat decreased intensity of cellular immunostaining for phospho-connexin43 (S368), and markedly decreased density at cell-cell contacts of immunostaining for phospho-connexin 43 (S368) (Figure 12H) compared with cells exposed to $16 \mathrm{nmol} / \mathrm{L}$ TPA for $1 \mathrm{~h}$ (Figure $12 \mathrm{G})$. The different immunostaining patterns observed after $0.5 \mathrm{~h}$ and $2 \mathrm{~h}$ of exposure to TPA suggest that phosphorylation of connexin43 at serine 368 and localization of phospho-connexin43 (S368) at cell-cell interfaces were transient responses in $\mathrm{WB}^{\mathrm{r}}-\mathrm{F} 344$ cells that declined even in the continued presence of TPA.

\section{Discussion}

The increased expression in uterine muscle of connexin 43 at the end of gestation is critical for the development of the synchronized, forceful uterine contractions necessary for parturition (Garfield and Hayashi, 1981; Garfield et al., 1977; Orsino et al., 1996; Risek et al., 1990). Because the insecticide lindane ( $\gamma$-hexachlorocyclohexane) inhibits spontaneous uterine muscle contractions in vitro (Criswell and Loch-Caruso, 1999; Wang and Loch-Caruso, 2002) and gap junction-mediated intercellular communication in myometrial cell cultures (Criswell and Loch-Caruso, 1995; Criswell et al., 1995), it was used in the present study to test the hypothesis that lindane-induced inhibition of gap junction communication between myometrial cells requires phosphorylation of connexin43. In addition, the phorbol ester TPA and the WB ${ }^{\mathrm{r}}-\mathrm{F} 344$ cell line were included as positive controls for comparison to lindane and myometrial cells (Matesic et al., 1994; Oh et al., 1991, 1993; Ruch et al., 2001). Although gap junctions are important for uterine muscle function and phosphorylation is a mechanism of connexin43 regulation (Lampe and Lau, 2000), this is the first report to evaluate con- nexin43 phosphorylation as a mechanism of disruption of myometrial gap junctions.

The rapid, nearly complete and sustained inhibition of Lucifer yellow dye transfer between myometrial and WBr-F344 cells induced by exposure to $50 \mu \mathrm{mol} / \mathrm{L}$ lindane is in agreement with previous reports (Criswell and Loch-Caruso, 1995; Criswell et al., 1995; Guan et al., 1995; Krieger and Loch-Caruso, 2001). Additional reports indicate that lindane inhibits gap junctions in other cell types (Defamie et al., 2001; Fujita et al., 1998; Guan et al., 1995; Klaunig et al., 1990; Leibold and Schwarz, 1993; Levin and Mercola, 1999; Li and Mather, 1997; Mograbi et al., 2003; Ruch et al., 1987; Tsushimoto et al., 1983). Although not examined in the present study, a temporal biphasic recovery of gap junction communication was observed in myometrial cells after removal of lindane from cell culture media. This biphasic recovery was characterized by an initial rapid recovery followed by a sustained depression of gap junction communication (Loch-Caruso et al., 2003). In WB-F344 cells, complete recovery of dye coupling was observed $4 \mathrm{~h}$ after discontinuation of a 4-h exposure to $50 \mu \mathrm{mol} / \mathrm{L}$ lindane (Guan et al., 1995).

TPA inhibited gap junction intercellular communication in myometrial and WB $^{\mathrm{r}}$-F344 cells in a manner similar to lindane. Previous studies have shown TPA-induced inhibition of gap junction communication in WB-F344 cells (Matesic et al., 1994; Oh et al., 1991; Ren et al., 1998; Ruch et al., 2001; Upham et al., 1997), and the modest reversal of inhibition observed with $\mathrm{WB}^{\mathrm{r}}-\mathrm{F} 344$ cells after $2 \mathrm{~h}$ of continuous exposure to TPA is consistent with a previous report (Matesic et al., 1994). The present report is the first to show that TPA inhibits gap junction communication in myometrial cells.

In previous studies, a shift in the migration of connexin 43 by standard SDS-PAGE was prevented by treatment with alkaline phospha- 
tase, indicating that the slower migrating bands represent phosphorylated connexin43 isoforms (Matesic et al., 1994; Musil et al., 1990). Similarly, in our positive controls, we found that TPA treatment of $\mathrm{WB}^{\mathrm{r}}-\mathrm{F} 344$ cells substantially increased the abundance of a slower migrating connexin43 isoform (band P3) and that treatment with alkaline phosphatase prevented this shift in connexin43 migration, consistent with TPA-induced phosphorylation of connexin43 in $\mathrm{WB}^{\mathrm{r}}$-F344 cells. However, the slower migrating P3 band was observed only in $\mathrm{WB}^{\mathrm{r}}$-F344 cells exposed to TPA but not in $\mathrm{WB}^{\mathrm{r}}$-F344 cells exposed to lindane and not in myometrial cells exposed to either TPA or lindane. Similar to the present study, Guan and associates reported that lindane did not alter SDS-PAGE electrophoretic mobility of connexin43 in WBr-F344 cells (Guan et al., 1995). Thus, changes in the migration of connexin 43 by standard SDSPAGE were cell-specific and toxicant-specific. Moreover, inhibition of gap junction communication was independent of a shift towards the slower migrating P3 connexin43 isoform, because TPA inhibited gap junction communication in both myometrial and WBr-F344 cells yet only WBr-F344 cells exposed to TPA exhibited intensification of the P3 connexin43 isoform.

Mutation of connexin43 serine 368 to alanine prevents TPA-induced inhibition of gap junction communication (Lampe et al., 2000), providing strong evidence that inhibition of connexin43-mediated intercellular communication is dependent, at least in part, on phosphorylation of connexin43 at serine 368 (Lampe and Lau, 2000). Immunoblotting with an antibody specific for phospho-connexin43 (S368) revealed expression of phosphorylated isoforms of connexin43 in myometrial cells after exposure to lindane or TPA and in $\mathrm{WB}^{\mathrm{r}}$ F344 cells after exposure to lindane, even though these treatments failed to increase the density of the P3 band. The immunoblotting results demonstrated that phosphorylation of connexin43 at S368 and intensification of the slower migrating P3 isoform in standard SDSPAGE gels occurred independent of each other and in toxicant-specific and cell-specific manners.

In contrast, phospho-connexin43 (S368) immunoblots of protein from TPA-exposed $\mathrm{WB}^{\mathrm{r}}$-F344 cells revealed four clear bands corresponding to the $\mathrm{P} 0, \mathrm{P} 1, \mathrm{P} 2$, and $\mathrm{P} 3$ bands. These phospho-connexin43 (S368) immunoblot results with $\mathrm{WB}^{\mathrm{r}}$-F344 cells are consistent with a recent report that TPA treatment induces large increases in phosphorylation of connexin43 at S368 in CHO cells but not NRK cells, yet only the $\mathrm{CHO}$ cells show the characteristic shift of connexin43 bands in immunoblots (Solan et al., 2003).

Phosphorylation occurred overwhelmingly on the P1 isoform in control myometrial cells and predominated in the $\mathrm{P} 0$ connexin 43 isoform in control $\mathrm{WB}^{\mathrm{r}}-\mathrm{F} 344$ cells, indicating that phosphorylation of connexin43 at S368 occurred in unstimulated myometrial and WB $^{\mathrm{r}}$-F344 cells in the absence of a band shift to the more slowly migrating isoforms. Solan and colleagues recently showed that phosphorylation of connexin 43 at serine 368 occurs in unstimulated cells, also, concomitant with cell progression through the $\mathrm{S}$ phase of the cell cycle (Solan et al., 2003). Consequently, the phosphorylation observed in unstimulated cells in the present study may be related to normal cell cycling; however, additional experiments would be required to confirm this possibility. The preference of phosphorylation for the P1 isoform in myometrial cells, as opposed to the P0 isoform in $\mathrm{WB}^{\mathrm{r}}-\mathrm{F} 344$ cells, cannot be explained at this time.

Although TPA-induced inhibition of gap junction intercellular communication was associated with intensification of the phosphorylated P3 isoform in $\mathrm{WB}^{\mathrm{r}}-\mathrm{F} 344$ cells, as reported previously (Berthoud et al., 1993; Matesic et al., 1994; Oh et al., 1991), inhibition 
of Lucifer yellow dye transfer by TPA was not accompanied by a band shift of connexin 43 in myometrial cells. Similar to the present report, others have failed to observe a band shift of connexin43 in standard SDS-PAGE gels under conditions of inhibited gap junctions in other cell types (Cruciani et al., 1997; Guan et al., 1995; Hii et al., 1995; Kenne et al., 1994; Matesic et al., 1994; Rivedal et al., 1994; Upham et al., 1997)..

In untreated myometrial and $\mathrm{WB}^{\mathrm{r}}$-F344 cells, sparse punctate immunostaining with anti-phospho-connexin43 (S368) was observed at the cell-cell interfaces and in the perinuclear regions, as reported previously for untreated normal rat kidney (NRK) epithelial cells (Solan et al., 2003). The immunofluorescence staining patterns of myometrial cells exposed to lindane were consistent with the immunoblotting results, showing no observable changes in immunofluorescence localization or intensification compared with controls.

TPA, however, intensified punctate staining with anti-phospho-connexin43 (S368) in myometrial cells after $0.5 \mathrm{~h}$ and $4 \mathrm{~h}$ of exposure, but no increase of phosphorylation was evident in the immunoblots. The discrepancy between the myometrial cell staining and immunoblots may reflect a change of localization of phospho-connexin43 (S368) such that the phosphorylated connexin 43 became more aggregated in the cell after TPA treatment, allowing for greater immunofluorescent punctate staining.

In WB ${ }^{r}-\mathrm{F} 344$ cells, lindane treatment intensified immunostaining for phospho-connexin43 (S368) at cell-cell interfaces in a transient manner, peaking after $0.5 \mathrm{~h}$ of exposure and returning to control levels after $1 \mathrm{~h}$ of exposure (and sustained for at least $4 \mathrm{~h}$ ). However, lindane did not induce a connexin 43 band shift in SDS-PAGE gels nor did the density of bands increase after blotting with anti-phospho-connexin43 (S368), suggesting that the amount of phospho-connexin43
(S368) did not increase with lindane treatment. The discrepancy between the myometrial cell staining and immunoblot results may be explained by lindane-induced aggregation of phospho-connexin43 (S368), with aggregated phospho-connexin43 (S368) allowing for increased detection of punctate fluorescence signals. The transient pattern of immunostaining for phospho-connexin43 (S368) in myometrial cells shows that lindane's actions on phospho-connexin43 (S368) localization reverse in the continued presence of lindane. Because estimates of half-life of lindane in humans range from $18 \mathrm{~h}$ to $111 \mathrm{~h}$, it is unlikely that the transient immunostaining of phosphoconnexin43 (S368) in myometrial cells was due to lindane metabolism or degradation.

TPA also intensified punctate staining with anti-phospho-connexin43 (S368) in $\mathrm{WB}^{\mathrm{r}}-\mathrm{F} 344$ cells, and the staining was substantially more intense in $\mathrm{WB}^{\mathrm{r}}$-F344 cells compared with myometrial cells exposed to TPA. The increased intensity of immunostaining in $\mathrm{WB}^{\mathrm{r}}$-F 344 cells is in agreement with the immunoblot data that showed increased density of phospho-connexin43 (S368) for $\mathrm{WB}^{\mathrm{r}}$-F344 cells but not myometrial cells.

In addition, the intensity of immunostaining with anti-phospho-connexin43 (S368) and the localization of phospho-connexin43 (S368) at cell-cell interfaces were greatest in $\mathrm{WB}^{\mathrm{r}}-\mathrm{F} 344$ cells after $0.5 \mathrm{~h}$ of exposure to TPA but declined noticeably by $2 \mathrm{~h}$, in contrast to myometrial cells in which the staining intensity and pattern did not substantially differ with TPA exposure durations ranging from $0.5 \mathrm{~h}$ to $4 \mathrm{~h}$. The differences between the cell immunostaining patterns of the myometrial and $\mathrm{WB}^{\mathrm{r}}$ F344 cells indicate cell-specific responses to TPA-induced phosphorylation of connexin 43 at S368.

The decreased intensity of immunostaining observed in WB ${ }^{\mathrm{r}}$-F344 cells after $2 \mathrm{~h}$ of exposure to TPA suggests that phosphorylation of connexin43 at serine 368 was a transient 
response in $\mathrm{WB}^{\mathrm{r}}$-F344 cells that declined even in the continued presence of TPA. The decreased intensity of cell immunostaining parallels the marked decline of the P3 isoform between $0.5 \mathrm{~h}$ and $2 \mathrm{~h}$ of exposure to TPA, as visualized by immunoblotting. It is unlikely that the transient nature of the TPA responses in $\mathrm{WB}^{\mathrm{r}}-\mathrm{F} 344$ cells were due to metabolism, because TPA is extremely stable in solution (manufacturer's Material Safety Data Sheet) and the half-life of TPA in human blood is estimated at $11 \mathrm{~h}$ (Cui et al., 2002). The concordance between the cell immunostaining and immunoblotting results provides further support that the SDS-PAGE gel band shift induced by TPA represents increased phosphorylation of connexin43, as suggested by others (Matesic et al., 1994; Oh et al., 1991). However, because phosphorylation of connexin43 also occurred without a band shift, the absence of a band shift was not evidence for absence of phosphorylation.

TPA-induced changes in cell localization of phospho-connexin43 (S368) in WB W $^{\mathrm{r}}$-F44 cells, as revealed by immunostaining, were accompanied by changes in cell shape. The changes in cell shape included decreased cell-cell contacts and were accompanied by substantially decreased immunostaining for phospho-connexin43 (S368) at cell-cell interfaces. These changes of cell shape and connexin43 localization may explain the decreased gap junction communication observed with TPA exposure of $\mathrm{WB}^{\mathrm{r}}-\mathrm{F} 344$ cells.

In a previous study with WB-F344 cells, Guan and colleagues (1995) reported that the connexin43 P2 isoform markedly decreased after $4 \mathrm{~h}$ of exposure to $50 \mu \mathrm{mol} / \mathrm{L}$ lindane. In contrast, the present study found no change in relative density of any of the connexin 43 isoforms in lindane-exposed WB $\mathrm{WB}^{\mathrm{r}}$-F344 cells. Because Lucifer yellow dye transfer appears to have been inhibited to a greater extent in the experiments of Guan and associates, one possible explanation for the discrepancy between the results of Guan and colleagues and those of the present study may be that the cell cultures of Guan and colleagues were more sensitive to lindane.

Based largely on studies with TPA, PKCmediated phosphorylation of connexin 43 has been suggested as a mechanism by which some agents inhibit connexin43 gap junctions (Lampe and Lau, 2000). Because lindane activates PKC and inhibits gap junction intercellular communication in myometrial cells, it was suggested that lindane may inhibit myometrial gap junctions, at least in part, due to phosphorylation of connexin43 (Criswell et al., 1995). Alternatively, lindane-induced inhibition of gap junction communication and endocytosis of connexin 43 have been associated with activation of the ERK pathway in Sertoli cells (Mograbi et al., 2003). Ruch and colleagues suggested that ERK activation via PKC mediates TPA-induced inhibition of gap junction communication in WB-F334 cells (Ruch et al., 2001). Although the present study fails to support phosphorylation of connexin 43 as a mechanism of lindane-induced inhibition of myometrial gap junctions, further research is needed to determine whether PKC or ERK pathways are involved. The possibility of a phosphorylation-independent mechanism for TPA-induced inhibition of gap junctions is suggested by a report that TPA decreases gap junction-mediated unitary conductance in cells transfected with the non-phosphorylated connexin, connexin26 (Kwak et al., 1995)

The present study shows that lindaneinduced and TPA-induced inhibition of gap junction communication occurred in myometrial cells independent of connexin 43 phosphorylation, and that the relationship between inhibition of gap junction communication and connexin43 phosphorylation was cell-specific and toxicant-specific. Moreover, the present study fails to support a mechanistic role for phosphorylation of connexin43 in lindaneinduced inhibition of myometrial gap junctions. 


\section{Acknowledgments}

We thank Martha Frenstrom and Dr Randall Ruch for assistance in the teaching of Western blotting techniques, Dr James Trosko for providing us the rat epithelial $\mathrm{WB}^{\mathrm{r}}-\mathrm{F} 344$ cells, and Dr Matesic for providing us with Western blot data on WB $^{\text {r }}$-F344 cells. We also thank Dr Harris for providing rat uteri and Vincent Peterkin for helping with the preparation of the figures. This research was supported by NIEHS grants to R.L.-C. (ES04424 and 04911).

\section{References}

Berthoud VM, Ledbetter ML, Hertzberg EL Saez JC. Connexin43 in MDCK cells: regulation by a tumor-promoting phorbol ester and Ca2+. Eur J Cell Biol. 1992;57:40-50.

Berthoud VM, Rook MB, Traub O, Hertzberg EL Saez JC. On the mechanisms of cell uncoupling induced by a tumor promoter phorbol ester in clone 9 cells, a rat liver epithelial cell line. Eur J Cell Biol. 1993;62:384-96.

Caruso RL, Juberg DR, Caldwell V Corcos IA. Cultured myometrial cells establish communicating gap junctions. Cell Biol Int Rep. 1990;14:905-16.

Castagna M, Takai Y, Kaibuchi K, Sano K, Kikkawa U Nishizuka Y. Direct activation of calcium-activated, phospholipid-dependent protein kinase by tumor-promoting phorbol esters. J Biol Chem. 1982;257:7847-51.

Criswell K Loch-Caruso R. Lindane-induced inhibition of spontaneous contractions of pregnant rat uterus. Reprod Toxicol. 1999;13:481-90.

Criswell KA Loch-Caruso R. Lindane-induced elimination of gap junctional communication in rat uterine myocytes is mediated by an arachidonic acid-sensitive cAMP-independent mechanism. Toxicol Appl Pharmacol. 1995;135:12738 .

Criswell KA, Loch-Caruso R Stuenkel EL. Lindane inhibition of gap junctional communication in myometrial myocytes is partially dependent on phosphoinositide-generated second messengers. Toxicol Appl Pharmacol. 1995;130:280-93.

Cruciani V, Mikalsen SO, Vasseur P Sanner T. Effects of peroxisome proliferators and 12-O-tetradecanoyl phorbol13-acetate on intercellular communication and connexin43 in two hamster fibroblast systems. Int J Cancer. 1997;73: 240-8.

Cui X, Chang R, Zheng X, Woodward D, Strair R, Conney A A sensitive bioassay for measuring blood levels of 12-Otetradecanoylphorbol-13-acetate (TPA) in patients: preliminary pharmacokinetic studies. Oncol Res. 2002;13:16974.
Defamie N, Mograbi B, Roger C, et al. Disruption of gap junctional intercellular communication by lindane is associated with aberrant localization of connexin43 and zonula occludens-1 in 42GPA9 Sertoli cells. Carcinogenesis. 2001; 22:1537-42.

Evans WH Martin PE. Gap junctions: structure and function (Review). Mol Membr Biol. 2002;19:121-36.

Fujita K, Nakanishi K, Sobue K, Ueki T, Asai K, Kato T. Astrocytic gap junction blockage and neuronal $\mathrm{Ca} 2+$ oscillation in neuron-astrocyte cocultures in vitro. Neurochem Int. 1998;33:41-9.

Garfield RE Hayashi RH. Appearance of gap junctions in the myometrium of women during labor. Am J Obstet Gynecol. 1981;140:254-60.

Garfield RE, Sims S Daniel EE. Gap junctions: their presence and necessity in myometrium during parturition. Science. 1977;198:958-60.

Godwin AJ, Green LM, Walsh MP, McDonald JR, Walsh DA, Fletcher WH. In situ regulation of cell-cell communication by the cAMP-dependent protein kinase and protein kinase C. Mol Cell Biochem. 1993;127-8:293-307.

Guan X, Bonney WJ, Ruch RJ. Changes in gap junction permeability, gap junction number, and connexin 43 expression in lindane-treated rat liver epithelial cells. Toxicol Appl Pharmacol. 1995;130:79-86.

Hii CS, Ferrante A, Schmidt S, et al. Inhibition of gap junctional communication by polyunsaturated fatty acids in WB cells: evidence that connexin 43 is not hyperphosphorylated. Carcinogenesis. 1995;16:1505-11.

Kenne K, Fransson-Steen R, Honkasalo S, Warngard L. Two inhibitors of gap junctional intercellular communication, TPA and endosulfan: different effects on phosphorylation of connexin 43 in the rat liver epithelial cell line, IAR 20. Carcinogenesis. 1994;15:1161-5.

Klaunig JE, Ruch RJ, Weghorst CM. Comparative effects of phenobarbital, DDT, and lindane on mouse hepatocyte gap junctional intercellular communication. Toxicol Appl Pharmacol. 1990;102:553-63.

Krieger TR Loch-Caruso R. Antioxidants prevent gammahexachlorocyclohexane-induced inhibition of rat myometrial gap junctions and contractions. Biol Reprod. 2001;64: 537-47.

Kwak BR, Hermans MM, De Jonge HR, Lohmann SM, Jongsma HJ, Chanson M. Differential regulation of distinct types of gap junction channels by similar phosphorylating conditions. Mol Biol Cell. 1995;6:1707-19.

Lampe PD, Lau AF. Regulation of gap junctions by phosphorylation of connexins. Arch Biochem Biophys. 2000;384:20515.

Lampe PD, TenBroek EM, Burt JM, Kurata WE, Johnson RG, Lau AF. Phosphorylation of connexin43 on serine 368 by protein kinase $\mathrm{C}$ regulates gap junctional communication. $\mathrm{J}$ Cell Biol. 2000;149:1503-12.

Lefebvre DL, Piersanti M, Bai XH, Chen ZQ, Lye SJ. Myometrial transcriptional regulation of the gap junction gene, connexin-43. Reprod Fertil Dev. 1995;7:603-11.

Leibold E, Schwarz LR. Inhibition of intercellular communication in rat hepatocytes by phenobarbital, 1,1,1-trichloro2,2-bis(p-chlorophenyl)ethane (DDT) and gamma-hexa- 
chlorocyclohexane (lindane): modification by antioxidants and inhibitors of cyclo-oxygenase. Carcinogenesis. 1993;14: 2377-82.

Levin M, Mercola M. Gap junction-mediated transfer of leftright patterning signals in the early chick blastoderm is upstream of Shh asymmetry in the node. Development. 1999;126:4703-14

Li R, Mather JP. Lindane, an inhibitor of gap junction formation, abolishes oocyte directed follicle organizing activity in vitro. Endocrinology. 1997;138:4477-80.

Loch-Caruso RK, Criswell KA, Grindatti CM, Brant KA Sustained inhibition of rat myometrial gap junctions and contractions by lindane. Reprod Biol Endocrinol. 2003;1: 62

Matesic DF, Rupp HL, Bonney WJ, Ruch RJ, Trosko JE. Changes in gap-junction permeability, phosphorylation, and number mediated by phorbol ester and non-phorbolester tumor promoters in rat liver epithelial cells. Mol Carcinog. 1994;10:226-36.

Mograbi B, Corcelle E, Defamie N, et al. Aberrant Connexin 43 endocytosis by the carcinogen lindane involves activation of the ERK/mitogen-activated protein kinase pathway. Carcinogenesis. 2003;24:1415-23.

Murray AW, Fitzgerald DJ. Tumor promoters inhibit metabolic cooperation in cocultures of epidermal and 3T3 cells. Biochem Biophys Res Commun. 1979;91:395-401.

Musil L, Cunningham B, Edelman G, Goodenough D. Differential phosphorylation of the gap junction protein connexin43 in junctional communication-competent and -deficient cell lines. J Cell Biol. 1990;111:2077-88.

Musil L, Goodenough D. Biochemical analysis of connexin43 intracellular transport, phosphorylation, and assembly into gap junctional plaques. J Cell Biol. 1991;115:1357-74.

Musil LS, Beyer EC, Goodenough DA. Expression of the gap junction protein connexin43 in embryonic chick lens: molecular cloning, ultrastructural localization, and post-translational phosphorylation. J Membr Biol. 1990;116:163-75.

Nishizuka Y. Studies and perspectives of protein kinase C. Science. 1986;233:305-12.

Oh SY, Grupen CG, Murray AW. Phorbol ester induces phosphorylation and down-regulation of connexin 43 in WB cells. Biochim Biophys Acta. 1991;1094:243-5.

Oh SY, Schmidt SA, Murray AW. Epidermal growth factor inhibits gap junctional communication and stimulates serine-phosphorylation of connexin 43 in WB cells by a protein kinase C-independent mechanism. Cell Adhes Commun. 1993;1:143-9.

Orsino A, Taylor CV, Lye SJ. Connexin-26 and connexin-43 are differentially expressed and regulated in the rat myometrium throughout late pregnancy and with the onset of labor. Endocrinology. 1996;137:1545-53.

Ou CW, Orsino A, Lye SJ. Expression of connexin-43 and connexin-26 in the rat myometrium during pregnancy and labor is differentially regulated by mechanical and hormonal signals. Endocrinology. 1997;138:5398-407.

Ren P, de Feijter A, Paul D, Ruch R. Enhancement of liver cell gap junction protein expression by glucocorticoids. Carcinogenesis. 1994;15:1807-13.

Ren P, Mehta PP, Ruch RJ. Inhibition of gap junctional intercellular communication by tumor promoters in connexin43 and connexin32-expressing liver cells: cell specificity and role of protein kinase C. Carcinogenesis. 1998;19: 169-75.

Risek B, Guthrie S, Kumar N, Gilula NB. Modulation of gap junction transcript and protein expression during pregnancy in the rat. J Cell Biol. 1990;110:269-82.

Rivedal E, Yamasaki H, Sanner T. Inhibition of gap junctional intercellular communication in Syrian hamster embryo cells by TPA, retinoic acid and DDT. Carcinogenesis. 1994;15: 689-94.

Ruch RJ, Bonney WJ, Sigler K, et al. Loss of gap junctions from DDT-treated rat liver epithelial cells. Carcinogenesis. 1994;15:301-6.

Ruch RJ, Klaunig JE, Pereira MA. Inhibition of intercellular communication between mouse hepatocytes by tumor promoters. Toxicol Appl Pharmacol. 1987;87:111-20.

Ruch RJ, Trosko JE, Madhukar BV. Inhibition of connexin43 gap junctional intercellular communication by TPA requires ERK activation. J Cell Biochem. 2001;83:163-9.

Solan JL, Fry MD, TenBroek EM, Lampe PD. Connexin43 phosphorylation at S368 is acute during S and G2/M and in response to protein kinase C activation. J Cell Sci. 2003;116: $2203-11$.

Tsushimoto G, Chang CC, Trosko JE, Matsumura F. Cytotoxic, mutagenic, and cell-cell communication inhibitory properties of DDT, lindane, and chlordane on Chinese hamster cells in vitro. Arch Environ Contam Toxicol. 1983;12:721-9.

Upham BL, Kang KS, Cho HY, Trosko JE. Hydrogen peroxide inhibits gap junctional intercellular communication in glutathione sufficient but not glutathione deficient cells. Carcinogenesis. 1997; 18:37-42.

Wang CT, Loch-Caruso R. Phospholipase-mediated inhibition of spontaneous oscillatory uterine contractions by lindane in vitro. Toxicol Appl Pharmacol. 2002;182:136-47.

Yotti LP, Chang CC, Trosko JE. Elimination of metabolic cooperation in Chinese hamster cells by a tumor promoter. Science. 1979;206:1089-91.

Address for correspondence: Dr Rita Loch-Caruso, Toxicology Program, Department of Environmental Health Sciences, The University of Michigan, 1420 Washington Heights, Ann Arbor, MI 48109-2029, USA

E-mail: rlc@umich.edu 